SGW-47839

Revision 0

\title{
Interpretation of Airborne Electromagnetic and Magnetic Data in the 600 Area
}

Prepared for the U.S. Department of Energy

Assistant Secretary for Environmental Management

Contractor for the U.S. Department of Energy

under Contract DE-AC06-08RL14788

CH2MHILL

Plateau Remediation Company

P.O. Box 1600

Richland, Washington 99352 
SGW-47839

Revision 0

\section{Interpretation of Airborne Electromagnetic and Magnetic Data in the 600 Area}

Date Published

September 2010

Prepared for the U.S. Department of Energy

Assistant Secretary for Environmental Management

Contractor for the U.S. Department of Energy

under Contract DE-AC06-08RL14788

CH2MHILL

Plateau Remediation Company

P.O. Box 1600

Richland, Washington

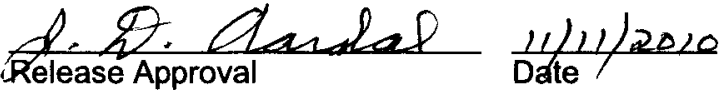


TRADEMARK DISCLAIMER

Reference herein to any specific commercial product, process,

or service by trade name, trademark, manufacturer, or

otherwise, does not necessarily constitute or imply its

endorsement, recommendation, or favoring by the United

States Government or any agency thereof or its contractors or subcontractors.

This report has been reproduced from the best available copy.

Printed in the United States of America 
SGW-47839 REV. 0

\section{CONTENTS}

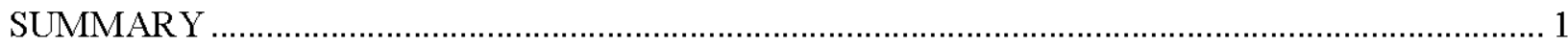

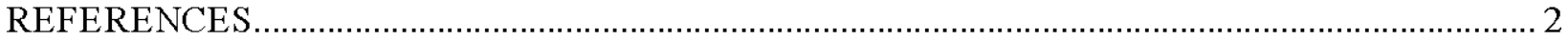

APPENDIX

A. EM INTERPRETATION OF AIRBORNE RESOLVE® AND HeliGEOTEM® II

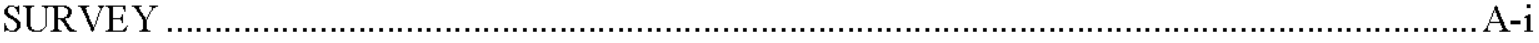


SGW-47839 REV. 0

\section{Terms}

\begin{tabular}{|c|c|}
\hline AEM & airborne electromagnetic \\
\hline AMSL & above mean sea level \\
\hline bgs & below ground surface \\
\hline BWIP & Basalt Waste Isolation Project \\
\hline $\mathrm{CMP}$ & common midpoint \\
\hline CSM & conceptual site model \\
\hline EM & electromagnetic \\
\hline FY & fiscal year \\
\hline HEIS & Hanford Environmental Information System \\
\hline HF1 & Hanford Formation Unit 1 \\
\hline $\mathrm{HF} 2$ & Hanford Formation Unit 2 \\
\hline HF3 & Hanford Formation Unit 3 \\
\hline IGRF & International Geomagnetic Reference Field \\
\hline LERF & Liquid Effluent Retention Facility \\
\hline LIGO & Laser Interferometer Gravitational-Wave Observatory \\
\hline OU & operable unit \\
\hline RDI & Resistivity-Depth-Image \\
\hline RI & remedial investigation \\
\hline RMI & residual magnetic intensity \\
\hline $\mathrm{rms}$ & root-mean-square \\
\hline RRL & Reference Repository Location \\
\hline SP & shot point \\
\hline TMI & total magnetic intensity \\
\hline WTP & Waste Treatment Plant \\
\hline
\end{tabular}




\section{SUMMARY}

As part of the 200-PO-1 Phase I geophysical surveys, Fugro ${ }^{1}$ Airborne Surveys was contracted to collect airborne electromagnetic (EM) and magnetic surveys of the Hanford Site 600 Area. Two helicopter survey systems were used with the HeliGEOTEM ${ }^{\circledR 2}$ time domain portion flown between June $19^{\text {th }}$ and June $20^{\text {th }}, 2008$, and the RESOLVE ${ }^{\circledR 3}$ frequency domain portion was flown from June $29^{\text {th }}$ to July $1^{\text {st }}, 2008$. Magnetic data were acquired contemporaneously with the electromagnetic surveys using a total-field cesium vapor magnetometer. Approximately 925 line kilometers $(\mathrm{km})$ were flown using the HeliGEOTEM ${ }^{\circledR}$ II system and 412 line kilometers were flown using the RESOLVE ${ }^{\circledR}$ system. The HeliGEOTEM system has an effective penetration of roughly 250 meters into the ground and the RESOLVE system has an effective penetration of roughly 60 meters. Acquisition parameters and preliminary results are provided in SGW-39674, Airborne Electromagnetic Survey Report, 200-PO-1 Groundwater Operable Unit, 600 Area, Hanford Site.

Airborne data are interpreted in this report in an attempt to identify areas of likely preferential groundwater flow within the aquifer system based on the presence of paleochannels or fault zones. The premise for the interpretation is that coarser-grained intervals have filled in scour channels created by episodic catastrophic flood events during the late Pleistocene. The interpretation strategy used the magnetic field anomaly data and existing bedrock maps to identify likely fault or lineament zones. Combined analysis of the magnetic, $60-\mathrm{Hz}$ noise monitor, and flight-altitude (radar) data were used to identify zones where EM response is more likely due to cultural interference and or bedrock structures. Cross-sectional and map view presentations of the EM data were used to identify more electrically resistive zones that likely correlate with coarser-grained intervals.

The resulting interpretation identifies one major northwest-southeast trending preferential flowpath with several minor units running along a similar trend. This presumed path of preferential flow is compared with the tritium concentration levels observed for the 600 Area. Analysis of the magnetic field data shows the location of potential bedrock faults and lineaments which may influence the horizontal and vertical flow of water. Faults lying within, or in the vicinity of preferential groundwater flow paths may allow flow into or out of the otherwise confined basalt layers

\footnotetext{
${ }^{1}$ Fugro is a registered trademark of Fugro Consultants International, B.V. LTD LIAB Co., Leidschendam, Netherlands.

2 HeliGEOTEM is a trademark of Fugro Airborne Surveys Corp., Ottawa, Ontario, Canada.

3 RESOLVE is a trademark of Fugro Airborne Surveys Corp., Ottawa, Ontario, Canada.
} 
SGW-47839 REV. 0

\section{REFERENCES}

SGW-39674, 2009, Airborne Electromagnetic Survey Report, 200-PO-1 Groundwater Operable Unit, 600 Area, Hanford Site, Rev. 0, CH2M HILL Plateau Remediation Company, Richland, Washington. 
SGW-47839 REV. 0

APPENDIX A

INTERPRETATION OF AIRBORNE ELECTROMAGNETIC

AND MAGNETIC DATA IN THE 600 AREA 
SGW-47839 REV. 0

A-ii 
Fugro Airborne Surveys

EM INTERPRETATION REPORT

Airborne RESOLVE ${ }^{\circledR}$ and HeligEOTEM ${ }^{\circledR}$ II Survey

HANFORD SITE 600 AREA

RICHLAND, WASHINGTON

Job No. 10554

$\mathrm{CH} 2 \mathrm{M}$ Hill Plateau Remediation Company (CHPRC)

Acquired on Behalf of

Department of Energy, Richland Operations

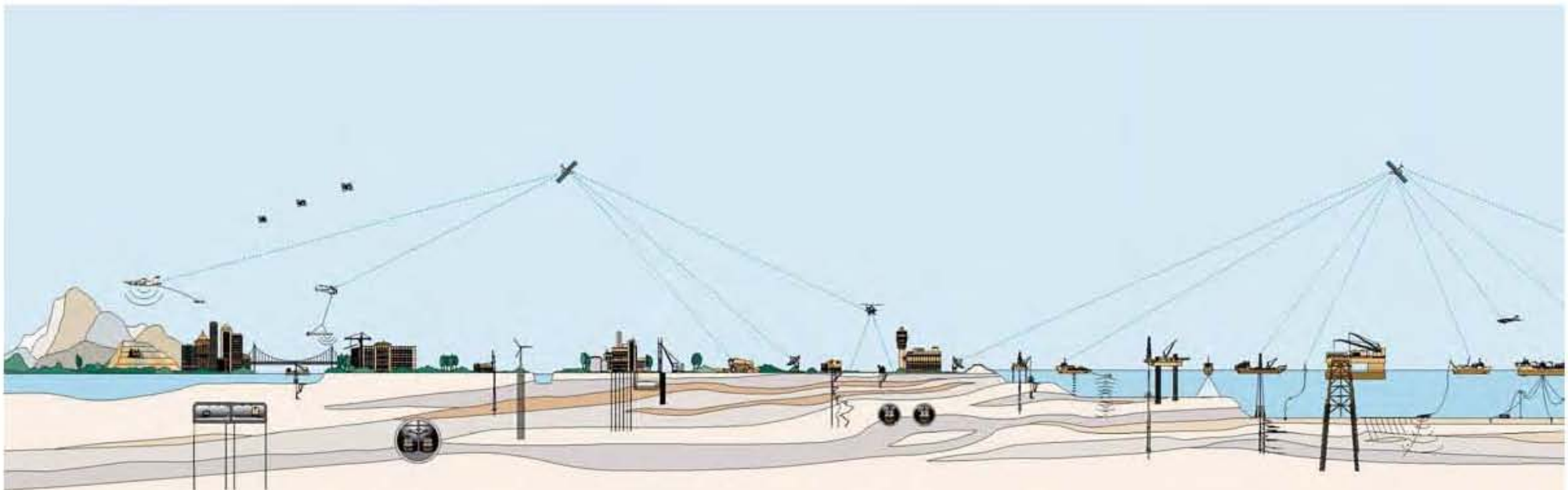


Fugro Airborne Surveys

\section{EM INTERPRETATION REPORT}

AIRBORNE RESOLVE ${ }^{\circledR}$ AND HELIGEOTEM ${ }^{\circledR}$ || SURVEY HANFORD SITE 600 AREA WASHINGTON

JOB NO. 10554

Client:

CHPRC

P. O. Box $1600, \mathrm{H} 8-42$

Richland, Washington

99352

Date of Report: September 15, 2010 


\section{TABLE OF CONTENTS}

INTRODUCTION

SURVEY OPERATIONS

Location of the Survey Area $\quad 6$

GEOLOGIC SETTING

Geology $\quad 7$

Hydrogeology and Hydrostratigraphy 9

INTERPRETATION 11

Magnetic Interpretation Procedures 11

Overview of the Magnetic Field 11

Overview of the Electromagnetic Field 13

Resistivity-Depth-images (RDI) - HeliGEOTEM 13

Resistivity-Depth Sections - RESOLVE 14

Electromagnetic interpretation Procedures 14

Comparison of HeliGEOTEM and RESOLVE data 18

Well Data and Cross-section Comparison with Survey Data 21

DISCUSSION 29

Resistive Near-surface Basalt 29

Interpreted Preferential Groundwater Flow Paths 32

CONCLUSIONS

35 


\section{TABLE OF FIGURES}

Figure 1: AS-350 B3 Helicopter similar to that used by Fugro Airborne Surveys. 5

Figure 2: Survey location 6

Figure 3: Generalized stratigraphy of the Hanford Site and the 200 East Area. 8

Figure 4: Water table and inferred flow directions in March 2008 (Hartman et al., 2009). 10

Figure 5: Grids of the Magnetic field products $\quad 12$

Figure 6: Resistivity Color Scheme $\quad 13$

Figure 7: Resistivity depth slices $\quad 16$

Figure 8: Effects of culture and high flying height on EM data 17

Figure 9: DTM grid and Resolve depth slices from surface down to about 50 meters. 18

Figure 10: Comparison of the RESOLVE $50 \mathrm{~m}$ depth slice and the HeliGEOTEM $50 \mathrm{~m}$ depth slice 19

Figure 11: Comparison of the apparent resistivity section and AIRbeo inversion for HeliGEOTEM line 10080 and RESOLVE resistivity section for line 10150.

Figure 12: Comparison of cross-sections and the HeliGEOTEM resistivity depth sections 22

Figure 13: Cross-section/RDI section comparison for cross-section E-E' 23

Figure 14: Cross-section/RDI section comparison for cross-section F-F' 24

Figure 15: Cross-section/RDI section comparison for cross-section G-G' 25

Figure 16: Cross-section/RDI section comparison for cross-section $\mathrm{H}^{-\mathrm{H}^{\prime}} \quad 26$

Figure 17: Cross-section/RDI section comparison for cross-section I-I' 27

Figure 18: Cross-section/RDI section comparison for cross-section J-J' 28

Figure 19: Zones interpreted as resistive basalt formations lying near-surface. 30

Figure 20: EM response to shallow basalt along cross-section H-H' and F-F' 31

Figure 21: Interpreted preferential groundwater flow paths displayed over the basalt elevation 33

Figure 22: Interpreted preferential groundwater flow paths displayed over the tritium plume 34 


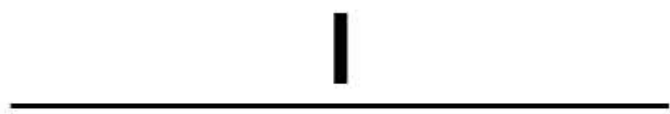

\section{Introduction}

Fugro Airborne Surveys conducted electromagnetic and magnetic surveys of the Hanford Site 600 Area for $\mathrm{CH} 2 \mathrm{M}$ Hill Plateau Remediation Company (CHPRC) on behalf of the Department of Energy, Richland Operations. The project used two helicopter survey systems, the HeliGEOTEM ${ }^{\circledR}$ II time domain portion was flown between June $19^{\text {th }}$ and June $20^{\text {th }}, 2008$, and the RESOLVE ${ }^{\circledR}$ frequency domain portion was flown from June $29^{\text {th }}$ to July $1^{\text {st }}, 2008$. Using Richland, Washington as the base of operations, 925 line kilometers $(\mathrm{km})$ were flown using the HeliGEOTEM ${ }^{\circledR}$ II system and 412 line kilometers were flown using the RESOLVE ${ }^{\circledR}$ system for a total of 1337 line kilometers of data, using an AS-350 B3 Helicopter (Figure 1). The HeliGEOTEM system has an effective penetration of roughly 250 meters into the ground and the RESOLVE system has an effective penetration of roughly 60 meters.

This report provides an interpretation of these datasets which will map the subsurface in an attempt to identify areas of preferential groundwater flow within the aquifer system beneath Hanford that result from the presence of permeable paleochannels (e.g. coarser-grained intervals) or along potential faults. The report includes an interpretation map showing the location of the interpreted preferential groundwater flow paths and potential faulting, along with an archive with apparent resistivity depth slices and sections.

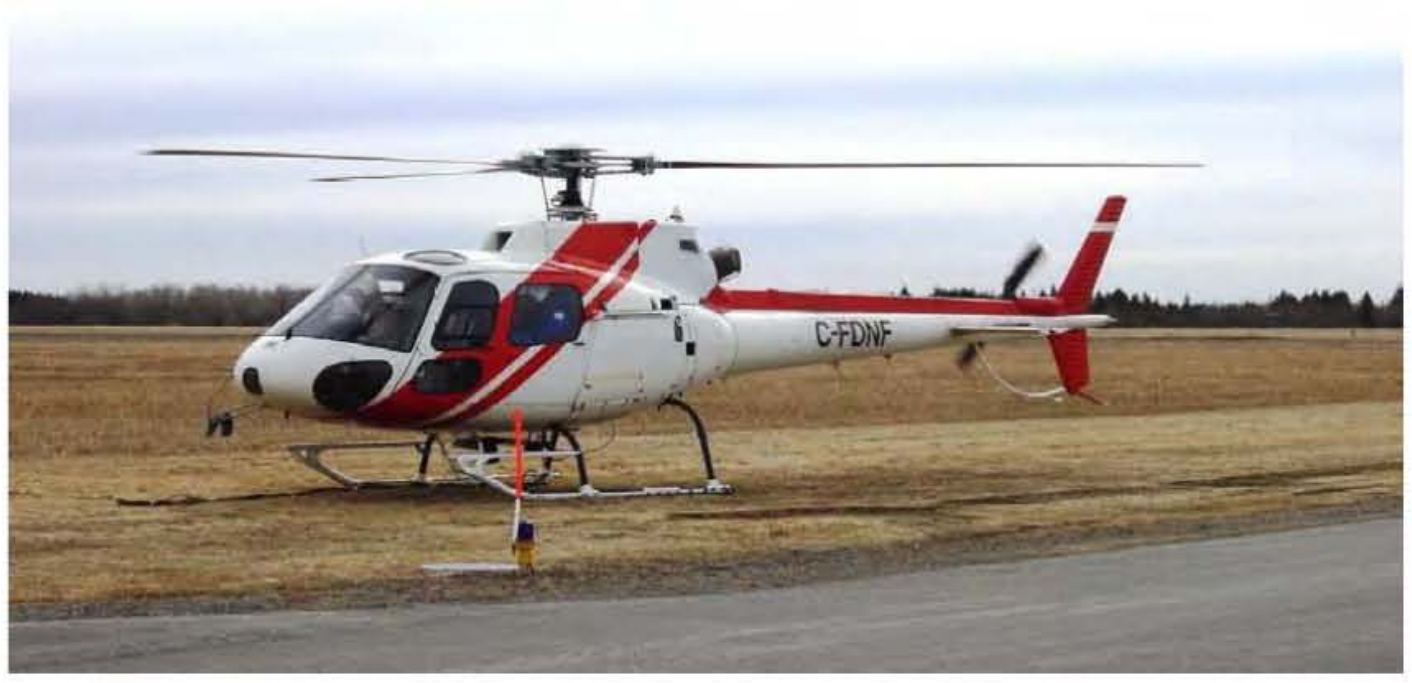

Figure 1: AS-350 B3 Helicopter similar to that used by Fugro Airborne Surveys. 


\section{Survey Operations}

\section{Location of the Survey Area}

The Hanford Site 600 Area (Figure 2) was flown with Richland, Washington as the base of operations. For the HeliGEOTEM II survey, a total of 55 traverse lines were flown ranging in length from $7 \mathrm{~km}$ to $21 \mathrm{~km}$, with a spacing of 400 meters between lines totalling $925 \mathrm{~km}$ for the survey. The RESOLVE survey coverage consisted of 23 traverse lines ranging in length from $16 \mathrm{~km}$ to 20 $\mathrm{km}$, flown at spacings of 100 and 200 meters for a total of $412 \mathrm{~km}$.

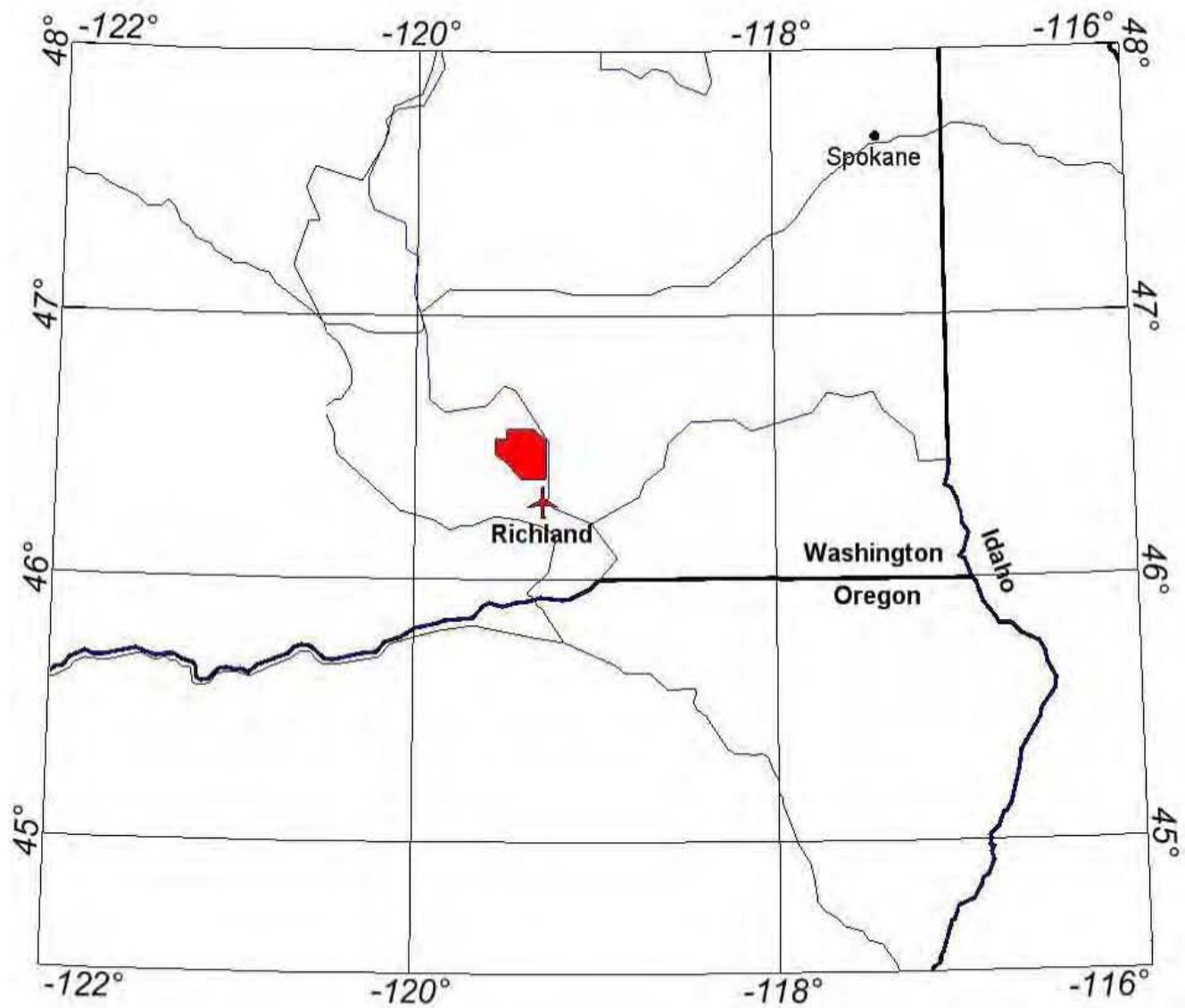

Figure 2: Survey location 


\section{Geologic Setting}

\section{Geology}

The general geologic setting of the Hanford site includes the Columbia River Basalt Group bedrock which lies near surface down to several hundred meters below ground surface. The basalt is overlain by gravel, sand, and clay deposits of the Ringold Formation and those deposits are overlain by the thick $(30-120 \mathrm{~m})$ unconfined, heterogeneous glacial-fluvial gravel, cobble, and sand deposits of the Hanford formation. A generalized stratigraphy of the Hanford Site is shown in Figure 3.

Both the Ringold and Hanford formations are the result of great floods and huge lakes covering the Hanford site at least during the past 3 million years. The Hanford Formation, for example, is composed of flood bar sediments deposited by the Missoula floods during the Pleistocene Epoch 1 million to 12,000 years ago. The Ringold formation is upper Miocene to Pliocene in age (10.5 to 3 million years ago) consisting of continental fluvial and lacustrine sediments deposited on the Elephant Mountain basalt by ancestral Columbia and Clearwater-Salmon rivers during late Miocene to middle-Pliocene time ${ }^{2,3}$. These formations are generally unconsolidated to semi-consolidated. These floods have both eroded channels in the substrate and deposited large quantities of poorlysorted sands and gravels ${ }^{2,4}$. These lakes may have reached a depth of several hundred meters. The resulting sediments also formed desiccation cracks that were filled with finer grained sediments than the surrounding matrix. These fine-grained sediments may act as vertical and horizontal clastic dikes that can control the movement of water and contaminates in the vadose zone and form localized confining layers such as in the lower Ringold Formation. In addition, channels cut in the basalt and Ringold formation that have been filled with sands and gravels may also control the movement of water and contaminates in the vadose zone. Erosion features associated with postRingold fluvial incision and Pleistocene cataclysmic flooding created a scoured and channeled surface that was later buried and is often difficult to map ${ }^{2}$. Within this buried paleo-channel and scoured area, Ringold-age sediments have been reworked and/or removed and younger, preMissoula gravels or the Hanford formation cataclysmic flood deposits of sand and gravel lie directly on top of basalt. Williams et al. (2000) believe that the erosion seen across the 200 Area was the result of a series of erosional events that scoured out some areas and leaving remnant mounds of

\footnotetext{
${ }^{1}$ Reidel, S.P., K.R. Fecht, 2005 Geology of the Integrated Disposal Facility Trench, Pacific Northwest National Laboratory document PNNL-15237.

${ }^{2}$ Williams B. A., B. N. Bjornstad, R. Schakka, and W. D. Webber, 2000, Revised Hydrogeobgy for the Suprabasalt Aquifer System, 200-East Area and Vicintity, Hanford Site, Washington, Pacific Northwest National Laboratory document PNNL-12261.

${ }^{3}$ Lindsey, K.A., 1995 Miocene- to Pliocene-Aged Suprabasalt Sediments of the Hanford Site, South-Central Washington, Bechtel Hanford, Inc., document BHI-00184 Rev. 00, U.S. Department of Energy, Office of Environmental Restoration and Waste Management, Richland, Washington.

${ }^{4}$ Gee, G.W., M. Oostrom, M.D. Freshley, M.L. Rockhold, and J.M. Zachara, 2007 Hanford Stre Vadoze Zone Studies: An Oveniew, in Vadose Zone Journal, Vol. 6, No. 4, p 899-905.
} 
Ringold sediments. This is principally based on well log discrepancies.

The youngest basalt flows of the Columbia River Basalt (CRB) Group are the Elephant Mountain Formation that is 10.5 million years old and ranges from 20 to 30 meters thick. The CRB group members have been folded and faulted to form Gable Mountain and Gable Butte. In addition, there are sub-surface anticlinal and synclinal structures present near Gable Mountain Pond that may have controlled some of the flood flows and channel development ${ }^{2}$. The geologic structures focused the flood energy, causing it to scour out the overlying Ringold sediments, and in some cases eroding down to and possibly into basalt bedrock. These channels were later filled by the younger Pleistocene Hanford sands and gravels. In fact, Williams (2000) suggests that the Columbia River shifted its course to the north of Gable Mountain after the ancestral river channel became plugged with flood deposits.

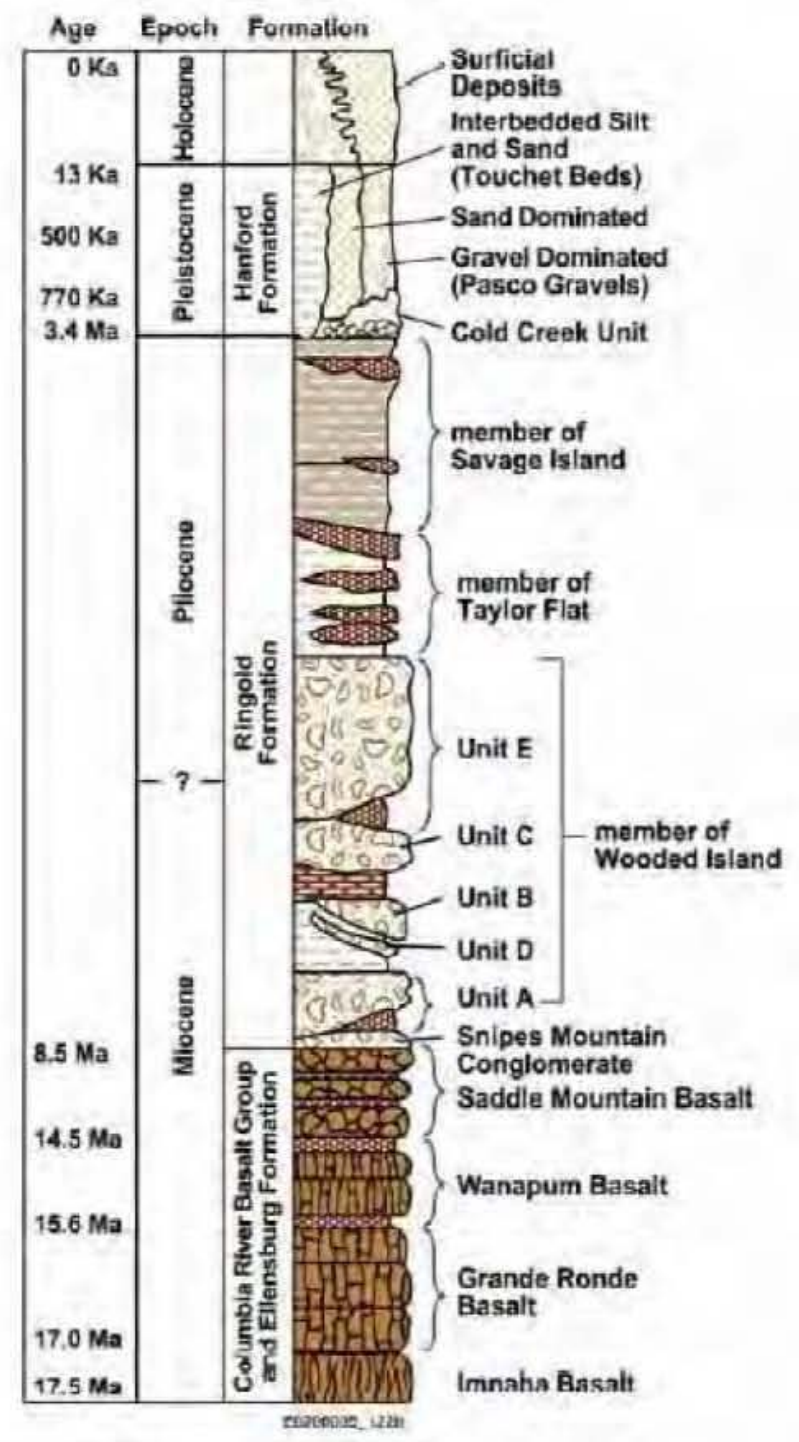

Figure 3: Generalized stratigraphy of the Hanford Site and the 200 East Area. 


\section{Hydrogeology and Hydrostratigraphy}

The water levels range from 100 meters below ground surface in the south to 65 meters bgs in the north. The direction of water flow across the Hanford site is from west to east. This is inferred from water-table elevations shown in Figure $4^{5}$. In the area north of the 200 East Area, the ground water generally has a shallow gradient and is moving north and west through the Gable Gap area through buried paleo-channels $\mathbf{s}^{2,6}$. Steeper ground water gradients to the west and east are associated with lower permeability sand and gravel of the Ringold Formation at the water table, while the shallower ground water gradients may be associated with higher permeable sand and gravel of the Hanford formation at the water table ${ }^{6}$. The higher permeability may have a direct relation to how quickly contaminants could reach the Columbia River.

The shallowest unit is the Hanford formation. These sediments were deposited between $\geq 3 \mathrm{Ma}$ and $13 \mathrm{Ka}$ and are composed of relatively unconsolidated pebble-to-boulder gravel, fine-to-coarsegrained sand, and silt-to-clayey silt ${ }^{2}$. This unit may lie unconformably on top of the basalt in the northern part of the study area. The Hanford formation hydraulic conductivity $(\mathrm{K})$ values are highest of all the hydrogeologic units present and may not have the cementation characteristics of the Ringold formation.

The Ringold is composed of continental fluvial and lacustrine sediments deposited above the Elephant Mountain basalt by ancestral Columbia and Clearwater-Salmon Rivers during late Miocene to middle-Pliocene time ${ }^{2}$. The unit consists of intercalated layers of indurated to semi-indurated and/or pedogenically altered sediment including clay, silt, fine-to coarse-grained sand, and granuleto-cobble gravel. Within most of the Ringold Formation there is a thick confining layer or lower mud composed of fluvial overbank, paleosol, and lacustrine silts and clay. This is between the Ringold Unit $\mathrm{A}$ and Unit $\mathrm{C}$ shown in Figure 3.

\footnotetext{
${ }^{5}$ Hartman, M.J., L.F. Morasch, W.D. Webber, 2007, Summary of Hanford Sthe Groundwater Montoring for Fiscal Year 2006, Pacific Northwest National Laboratory document PNNL-16346-SUM

${ }^{6}$ Hartman, M.J., V.S. Richie, J.A. Rediker, 2009, Hanford Sïe Groundwater Montioring for Fiscal Year 2008, $\mathrm{CH} 2 \mathrm{MH}$ ill Plateau Remediation Company document DOE/RL-2008-66 Draft A, U.S. Department of Energy, Richland, Washington.
} 


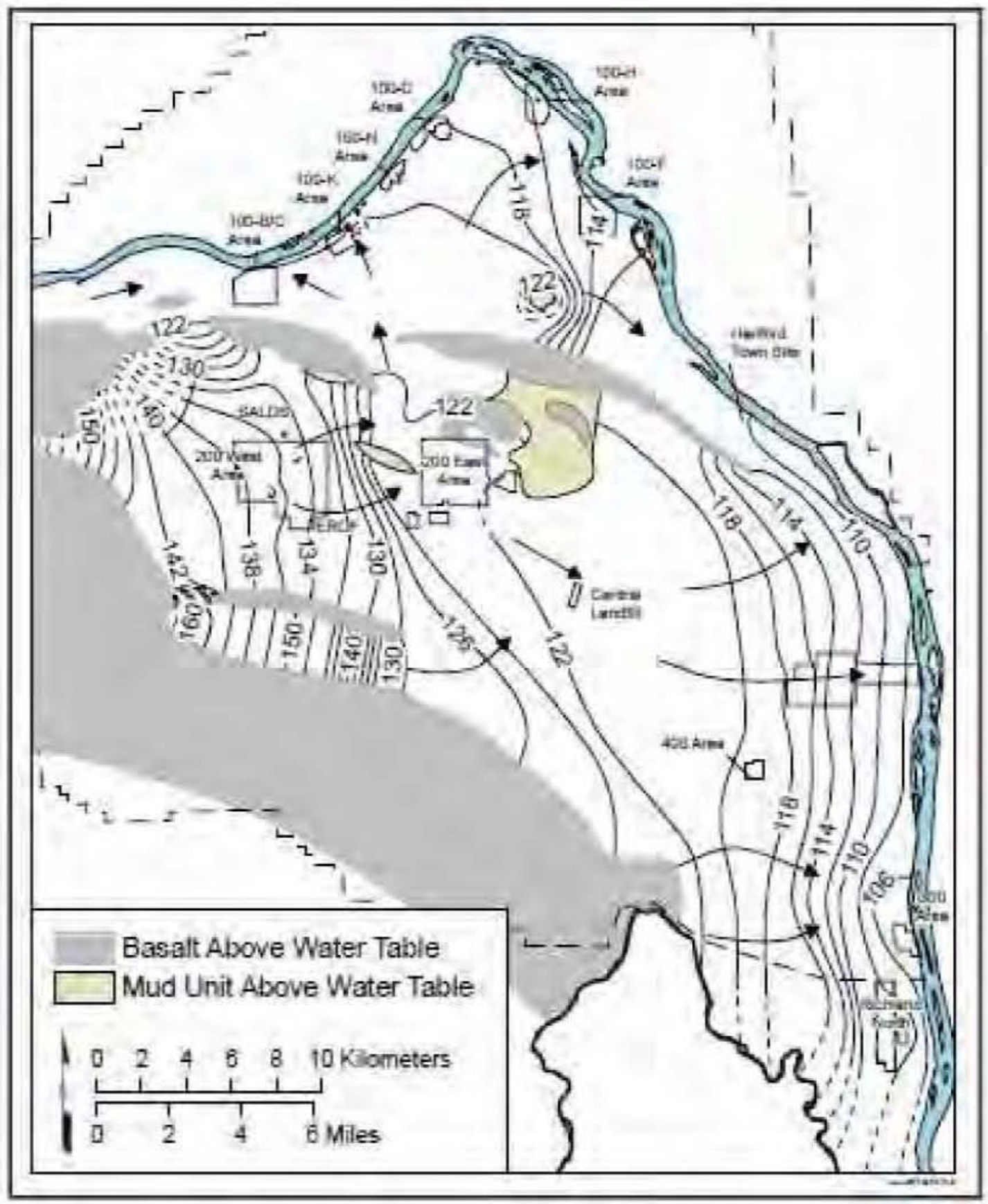

Figure 4: Water table and inferred flow directions in March 2008 (Hartman et al., 2009). 


\section{Interpretation}

\section{Magnetic Interpretation Procedures}

The residual magnetic intensity (RMI) is calculated from the total magnetic intensity (TMI), the diurnal, and the regional magnetic field. The TMI is measured in the aircraft, the diurnal is measured from the ground station and the regional magnetic field is calculated from the International Geomagnetic Reference Field (IGRF). The low frequency component of the diurnal is extracted from the filtered ground station data and removed from the TMI. The average of the diurnal is then added back in to obtain the resultant TMI. The regional magnetic field, calculated for the specific survey location and the time of the survey, is removed from the resultant TMI to obtain the RMI. The data are then tie line levelled and microlevelled as required, gridded and contoured.

The first vertical derivative was calculated in the frequency domain from the final grid values to enhance subtleties related to geological structures. A first vertical derivative has also been displayed in profile form. This was calculated from the line data by combining the transfer functions of the 1st vertical derivative and a low-pass filter (cut-off value $=0.0450$, roll-off value $=0.030$ ). The low-pass filter was designed to attenuate the high frequencies representing non-geological signal, which are normally enhanced by the derivative operator. The first vertical derivative data are then also gridded and contoured.

In the electromagnetic interpretation, magnetic features in the vicinity of conductive targets are studied with regard to shape, size, strike and grouping to aid the evaluation of conductors and their potential correlation with basement. Basement lineaments and potential faults relating to EM conductors are shown on the interpretation maps.

\section{Overview of the Magnetic Field}

The residual magnetic intensity and first vertical derivative grids for the survey area are shown in Figure 5, along with dashed linear features interpreted as potential faults and basement lineaments. The magnetic field grids show fairly long wavelength, low amplitude features as would be expected in an area of extensive sedimentary cover. Some of the shorter wavelength responses appear to be mapping out basalt formations which are approaching surface, such as the Gable Mountain Anticline along the northern part of the block. Several other of the more intense, shorter wavelength responses are likely mapping similar anticlines, contacts and faults in the bedrock.

Fault and lineament positions are determined by identifying linear trends and offsets in the gridded data. In this sort of environment with relatively thick layers of non-magnetic sediment overlying the more magnetic basement rock, it is often difficult to identify contacts and faults as the response from these features will be fairly long wavelength and may be partly masked by any weaker localized, near surface magnetic responses. The interpretation map displays the basement lineaments following the more intense, shorter wavelength features seen in the magnetic field grids. 

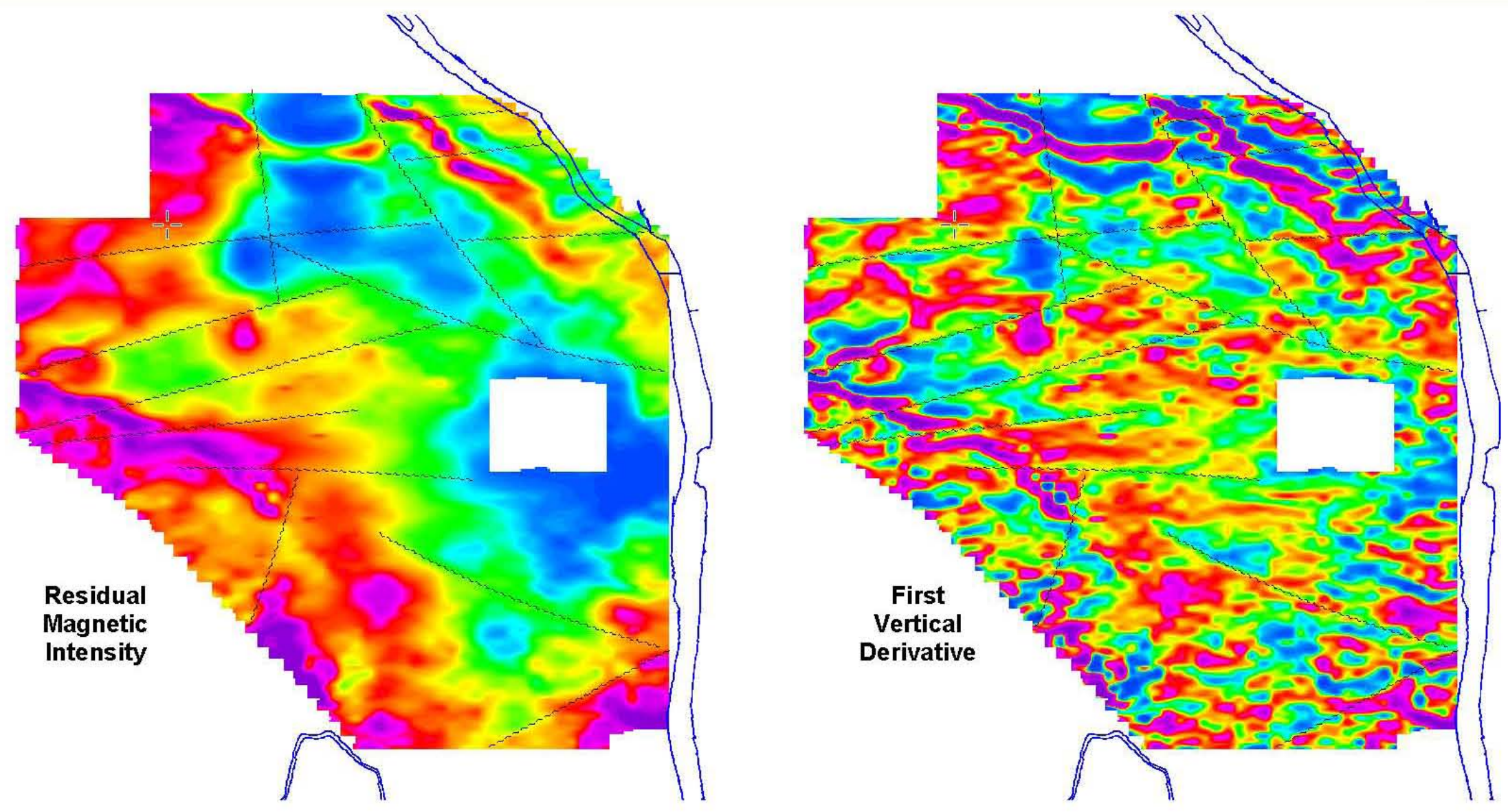

Figure 5: Grids of the Magnetic field products 
Overview of the Electromagnetic Field

\section{Resistivity-Depth-Images (RDI) - HeliGEOTEM}

For the HeliGEOTEM data, the Resistivity-Depth-Image (RDI) sections were calculated from the B Field Z-coil response, using an algorithm that converts the response in any measurement window (on- or off-time) into apparent resistivity. For on-time data, it is not straightforward to identify which depth the apparent resistivity is associated, or identify any variation in apparent resistivity with depth. Hence, the earth is assigned a constant value from surface to depth.

However, for the off-time data, the apparent resistivity can be associated with a depth. This depth, $\delta$, depends on the magnetic permeability $\mu$, the delay time $t$ of the measurement window and the estimated apparent conductivity $\sigma_{a p p}$, i.e.

$$
\delta=0.55 \sqrt{\frac{t}{\mu \sigma_{a p p}}} .
$$

The electromagnetic method is most sensitive to conductive features so resistive features will be poorly resolved. The process of converting voltage data to apparent resistivity as a function of depth tends to create smoother depth variations than can occur in reality.

The RDI sections, derived from each survey line, are created as individual grids. An additional set of RDI grids have been corrected for altitude variations such that the top of each section reflects the true terrain topography.

The RDI derived information is also stored in a Geosoft database as an array. The array consists of 60 levels of apparent resistivity, from 0 to 590 meters depth. The apparent resistivity values can be gridded to provide resistivity depth slices for desired depths. On this project, resistivity-depth slices were created at intervals of $10 \mathrm{~m}$ from surface to the depth of effective penetration which in this case was about 250 meters below the surface.

For the interpretation, all of the depth slice grids were checked for anomalous features, however, three grids were generated in order to represent a near surface or shallow view of the subsurface at roughly 50 meters, a middle depth at roughly 100 meters and a deeper view at roughly 160 meters. This is described more below.

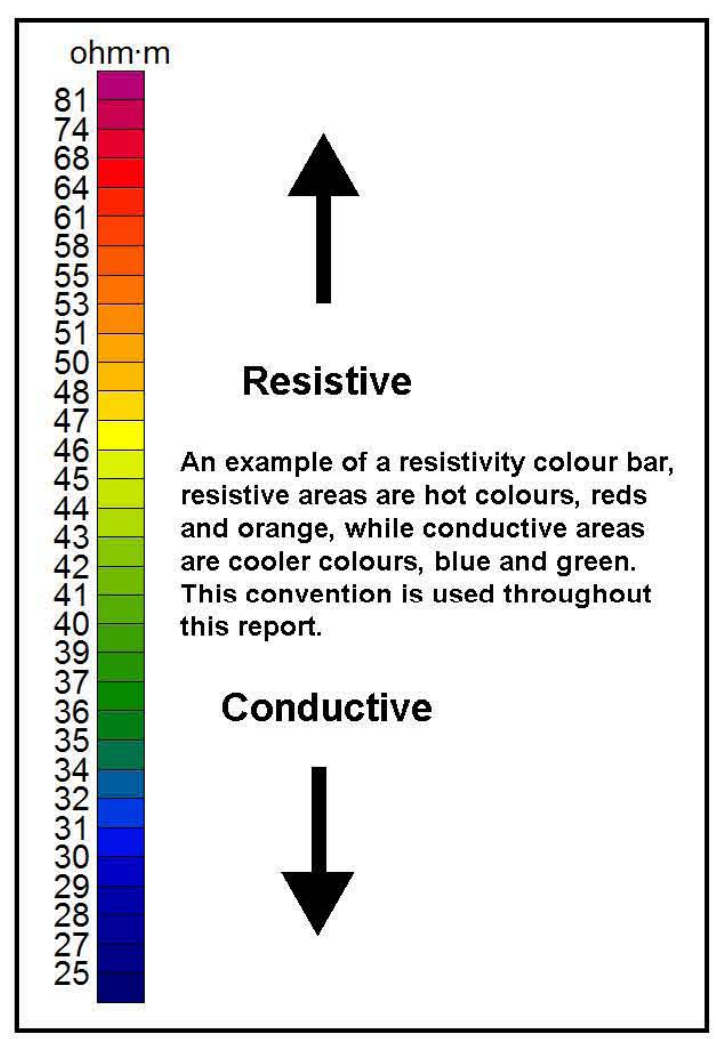

Figure 6: Resistivity Color Scheme 


\section{Resistivity-Depth Sections - RESOLVE}

The apparent resistivities for all frequencies can be displayed simultaneously as colored apparent resistivity-depth sections. Usually, only the coplanar data are displayed as the close frequency separation between the coplanar and adjacent coaxial data tends to distort the section. The sections can be plotted using the topographic elevation profile as the surface. The digital terrain values, in meters a.m.s.I., can be calculated from the GPS Z-value or barometric altimeter, minus the aircraft laser altimeter. For this project the resistivity-depth sections were generated as differential resistivity sections, where the differential resistivity is plotted at the differential depth ${ }^{7}$.

The differential method is derived from the pseudo-layer half-space model and yields a colored resistivity-depth section that attempts to portray a smoothed approximation of the true resistivity distribution with depth. Resistivity-depth sections are most useful in conductive layered situations, but may be unreliable in areas of moderate to high apparent resistivity where signal amplitudes are weak. In areas where in-phase responses have been suppressed by the effects of magnetite, or adversely affected by cultural features, the computed resistivities shown on the sections may be unreliable.

\section{Electromagnetic Interpretation Procedures}

The general approach to EM interpretation is two-fold. One is to work from the data in plan form (maps), correlating back to the data in profile form; the other is to work from the profiles back to the maps. The basis of target selection is to look for "anomalous" responses that correlate with features of interest such as preferential groundwater flow paths, presence of basement, and/or faulting. Some of these will stand out on the maps as somewhat isolated features along favourable structural intercepts. Conversely, some localized changes in conductivity may only be apparent in profile form and may not stand out on the maps due to interference or masking from surrounding conductive bodies. So, a general review of the EM responses in profile form is done to search for well-defined shape, moderate amplitude, slow decay, etc., then checked on the maps for strike length, structural (magnetic/geologic) support and overall conductivity pattern.

For this project the primary targets are zones showing slightly more resistive properties which are presumed to result from channel-like features likely infilled with coarser-grained deposits with increased hydraulic conductivity and/or permeability. In this case the majority of the targets are identified by studying resistivity depth slice and depth section grids, with the profile data used to help identify structures with vertical extent, to help correlate the EM data with the magnetic field data, and to help identify areas of cultural interference.

Identified resistive zones are compared with the magnetic signature to separate likely basement derived features (anomalous zones?) from those arising from within the sediments and overburden. The magnetic signature resulting from the basalt bedrock will generally show a stronger overall response with shorter wavelength anomalies, and can be used in identifying potential faults and contacts. Therefore, correlation with a stronger, shorter wavelength magnetic feature will often suggest the EM response is from a bedrock source rather than from zones within the near surface sedimentary layers.

\footnotetext{
${ }^{7}$ Huang, H. and Fraser, D.C., 1993, Differential Resistivity Method for Multi-frequency Airborne EM Sounding: presented at Intern. Airb. EM Workshop, Tucson, Ariz.
} 
Resistivity depth slices were generated at 10 meter intervals from surface down to near the effective depth of penetration of about 250 meters in the more conductive areas. Due to the broad footprint of the HeliGEOTEM system, changes in resistivity between the 10 meter intervals tends to be quite gradual. Therefore, to simplify the interpretation and to avoid having to examine numerous grids with only minor variations in resistivity from slice to slice, three averaged grids were generated to represent a shallow, middle depth and a deep slice. The shallow grid averaged the depth slices from 20, 40 and 60 meters, the middle depth grid averaged the 80,100 and 120 meter grids, and the deep grid averaged the 140,160 and 180 meter depths. A check of all grids was done to confirm that no features of interest were eliminated from the averaging, or missed on grids not used in the averaging.

These depths, of course, do not represent an exact depth from where the sensor is reading, but rather where theoretically the strongest EM signal is being generated as the signal decays within the ground. The depth of the preferential groundwater flow paths on the interpretation map are stated as shallow (roughly $40 \mathrm{~m}$ ), mid depth (roughly $100 \mathrm{~m}$ ) or deep (roughly $160 \mathrm{~m}$ ) depending on which of the three grids shows the strongest resistive feature. More accurate estimations of the depths would require additional modeling and inversion of the data which is beyond the scope of this interpretation.

The grey zones in Figure 7 below are areas affected by cultural noise and should be viewed with caution.

Power line and cultural interference is a major problem in this dataset, as displayed in Figure 8. Determining the lateral extent of flat-lying resistive bodies in the survey area is a critical part of the interpretation, however, the cultural noise makes it difficult to confidently determine the continuity of the areas of preferential groundwater flow throughout the block. Dashed outlines of the zones on the interpretation map identify parts of the preferential groundwater flow paths that lie within or close to the areas of cultural interference. 


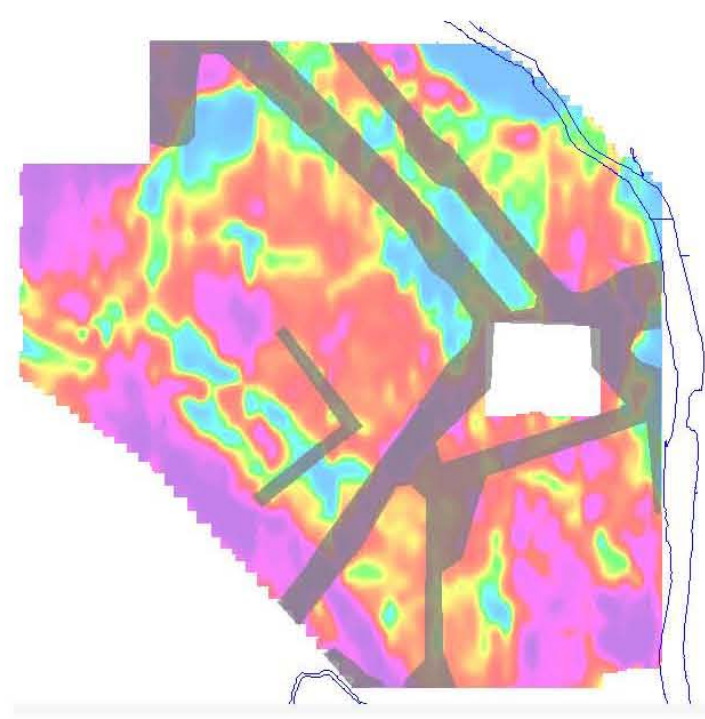

"Shallow" Resistivity Depth slice, roughly $\mathbf{4 0}$ meters

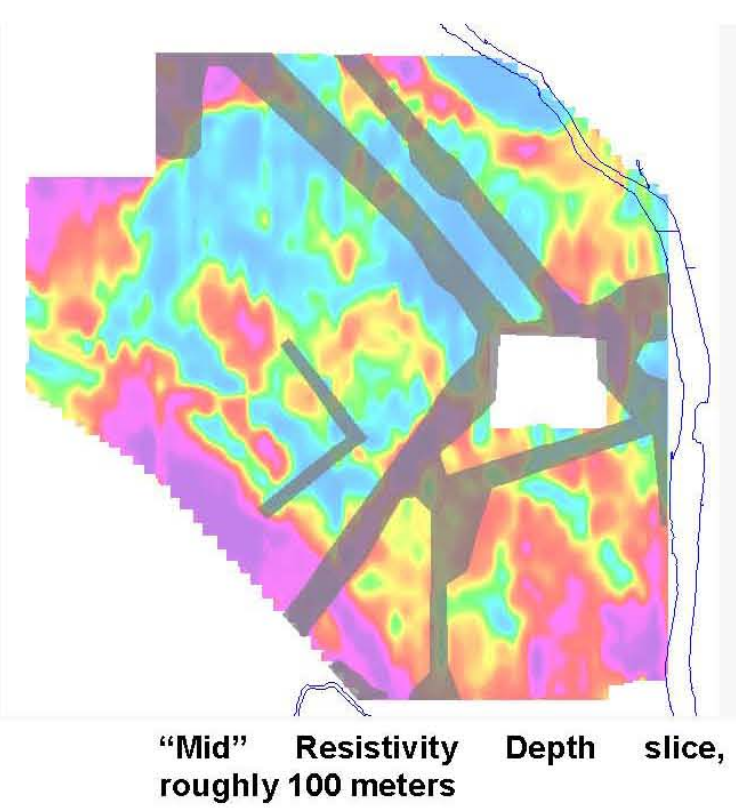

roughly 100 meters

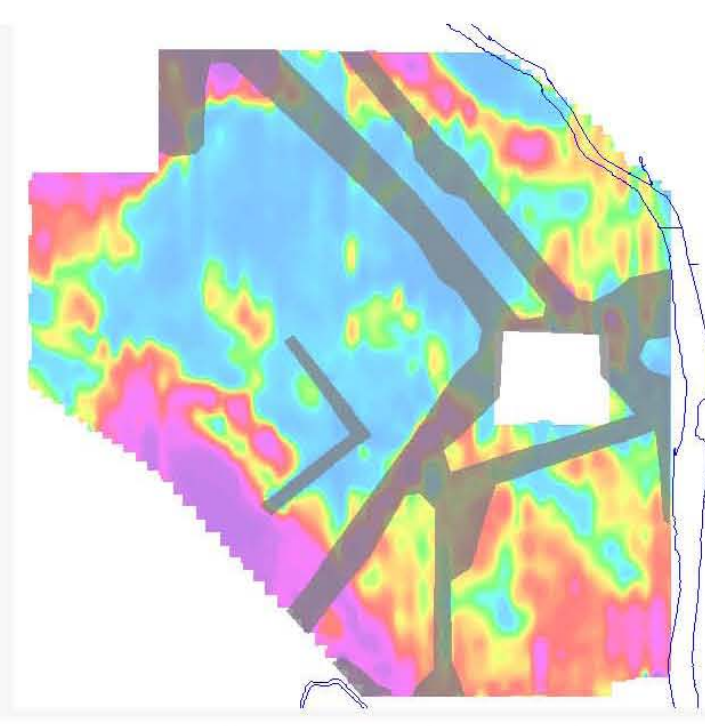

"Deep" Resistivity Depth slice, Roughly 160 meters

Figure 7: Resistivity depth slices 


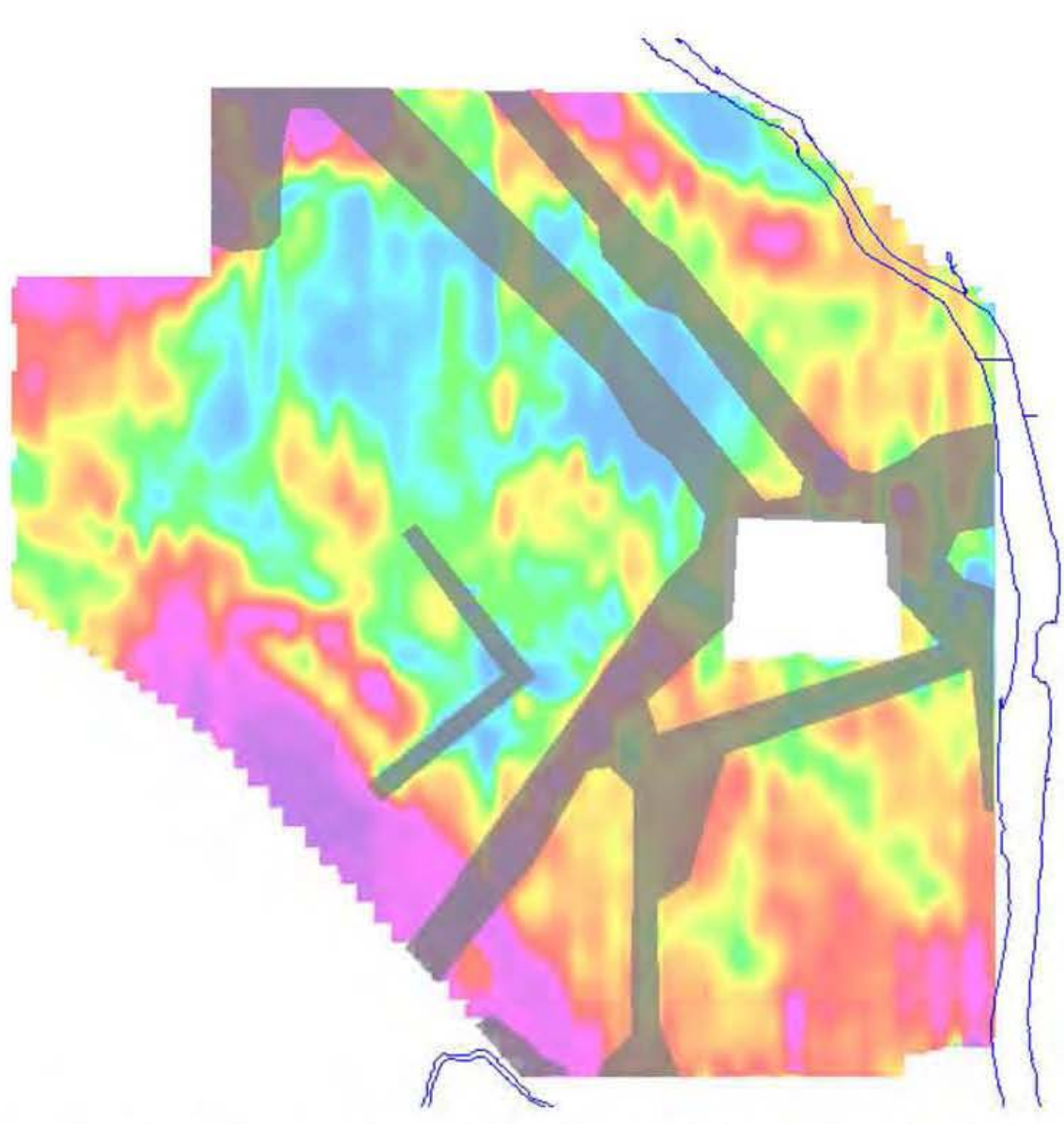

Areas of reduced data quality due to cultural interference and high flying height are shown as grey areas over resisitivity at a depth of about 100 meters

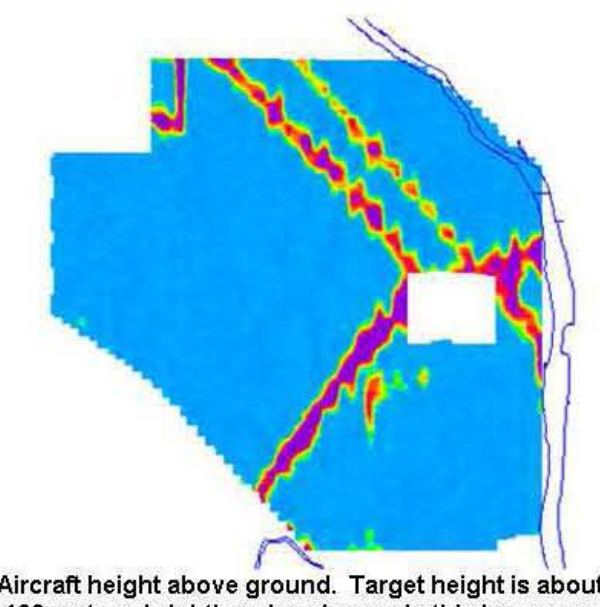
Aircraft height above ground. Target height is about
100 meters, brightly colored areas in this image are above 130 meters

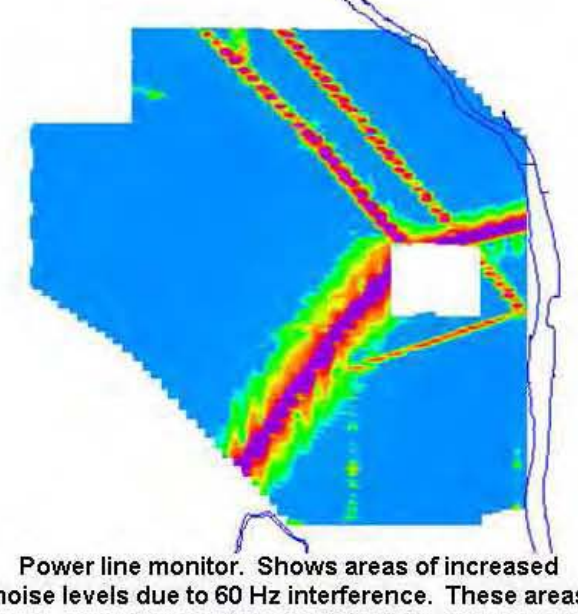
are usually coincident with high flying areas.
.

Figure 8: Effects of culture and high flying height on EM data 


\section{Comparison of HeliGEOTEM and RESOLVE data}

The eastern part of the survey area adjacent to the Columbia River was flown with both the HeliGEOTEM system and the RESOLVE system. HeliGEOTEM is a time-domain system which is more powerful resulting in a deeper penetration depth, but also has a broader footprint and is generally flown with a larger line spacing which results in lower resolution. RESOLVE is a frequency domain system which is less powerful resulting in a shallower depth of penetration, but is generally flown with a tighter line spacing, closer to the ground resulting in a higher resolution. Because of these properties of the systems, the best comparison of the two datasets would be a deep resistivity depth slice from the RESOLVE system, and a shallow resistivity depth slice from the HeliGEOTEM system. Figure 10 shows a depth slice from roughly 50 meters for both systems.

Resistivity grids from the RESOLVE data are displayed in Figure 9 from surface down to about 50 meters at 10 meter intervals using the same color scheme. Examining the drill logs along crosssection $\mathrm{J}-\mathrm{J}$ ', it appears that the RESOLVE data is penetrating into the upper Ringold formations but is not likely to be measuring any signal from the basalts which lie at a minimum of 60 meters in some of the southern parts of the RESOLVE coverage, but lies at 100 meters or deeper for the rest of the surveyed area. The surface down to the 20 meter resistivity grids are likely responding to recent surficial fill and features within the Hanford formation, note the strong correlation with the DTM grid. The 30 to 50 meter grids likely represent parts of the Hanford, Cold Creek and Upper Ringold units. The potential preferential groundwater flow paths shown on the interpretation map derived from the RESOLVE data appear to be located at the base of the Hanford Formation and in the upper units of the Ringold formation.

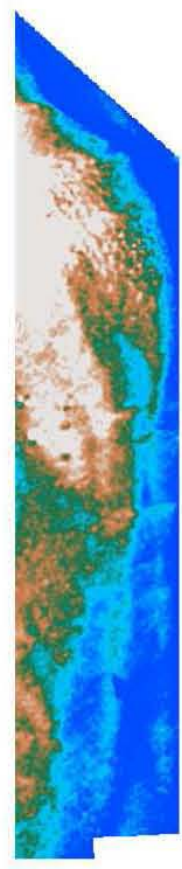

DTM

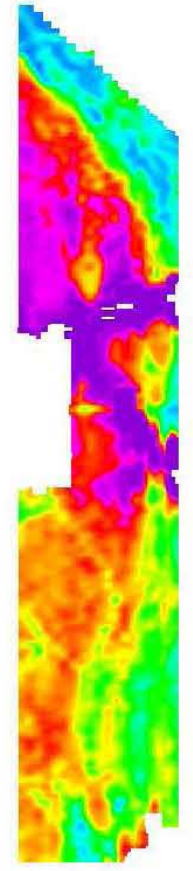

Surface

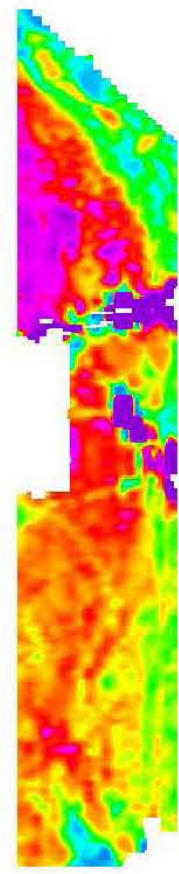

10 meters

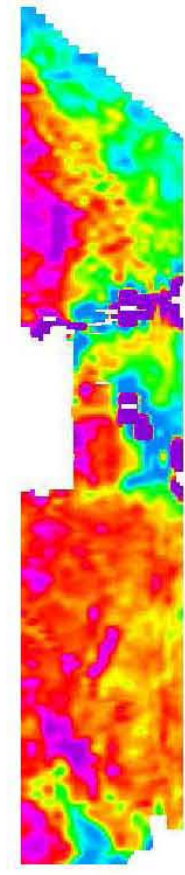

20 meters

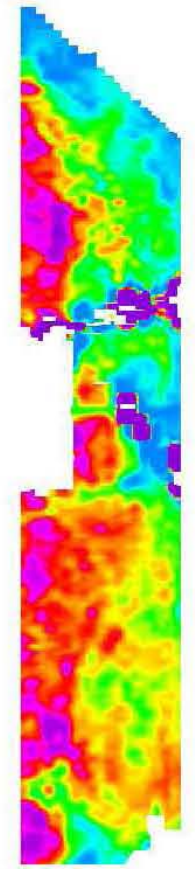

30 meters

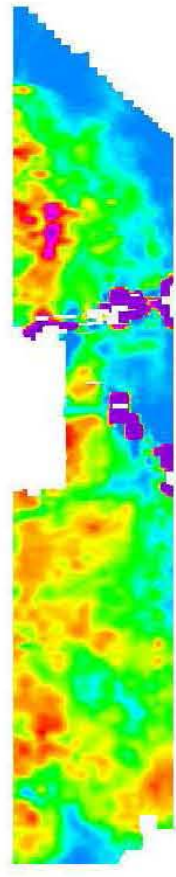

40 meters

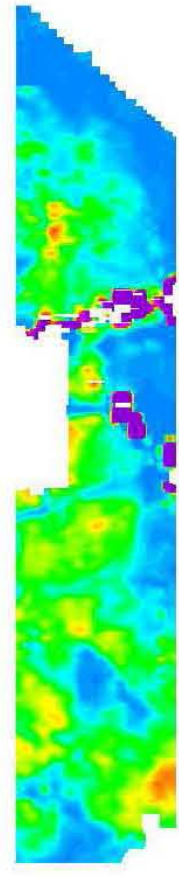

50 meters

Figure 9: DTM grid and Resolve depth slices from surface down to about 50 meters. 
Comparison of the "deeper" RESOLVE (left) and "shallower" HeliGEOTEM (right) apparent resistivity depth slices are shown in Figure 10. The red outlines on both images show the potential near surface paleochannels or preferential groundwater flow paths interpreted from the RESOLVE data. Similarities are evident, however, it is clear that the RESOLVE data results in a more detailed, higher resolution grid. The HeliGEOTEM grid is also likely mapping some deeper features due to the broader footprint of the system. Grey zones are areas affected by cultural noise and/or changes in flight elevation.
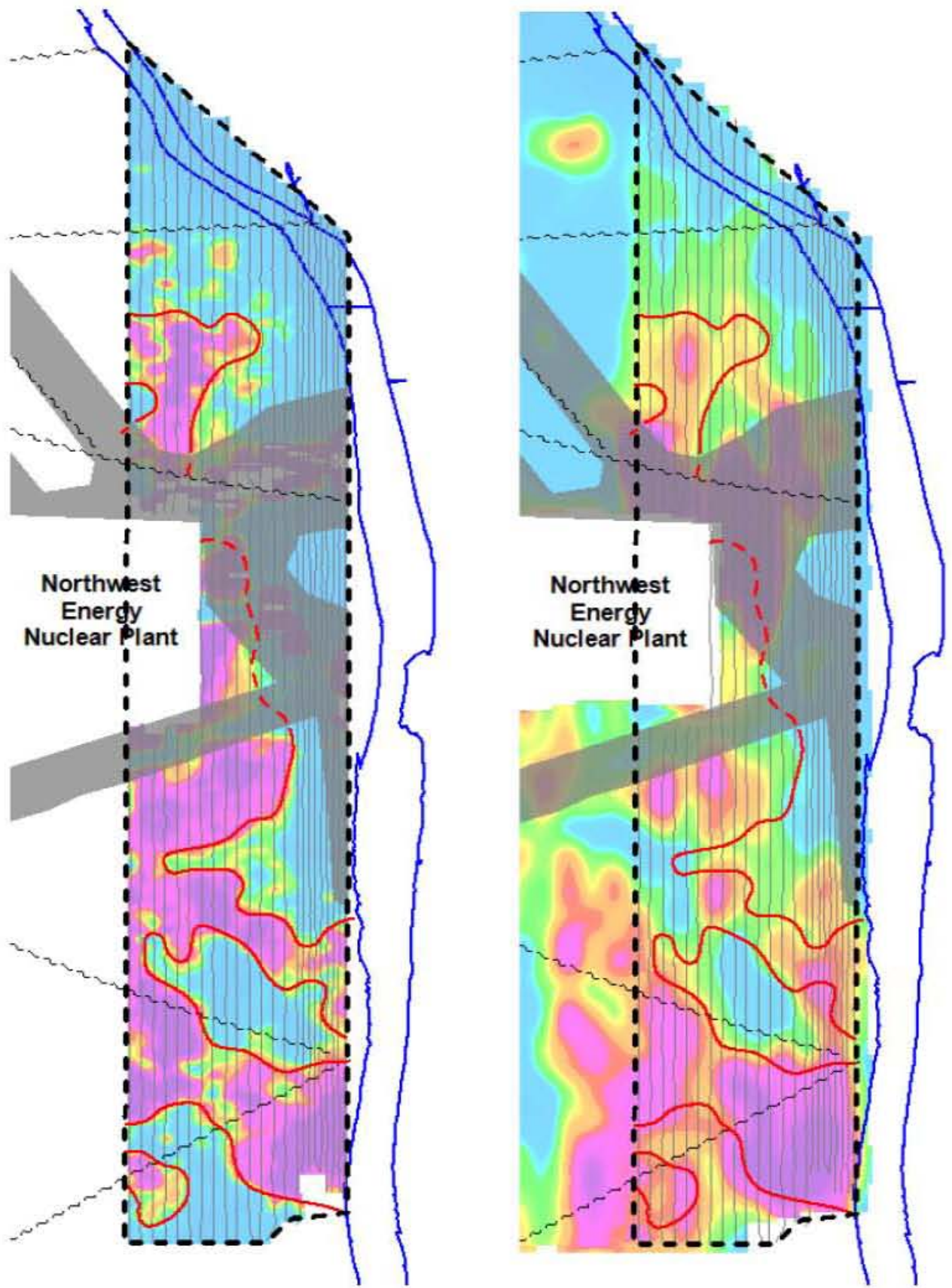

Figure 10: Comparison of the RESOLVE 50 meter depth slice and the HeliGEOTEM 50 meter depth slice. 


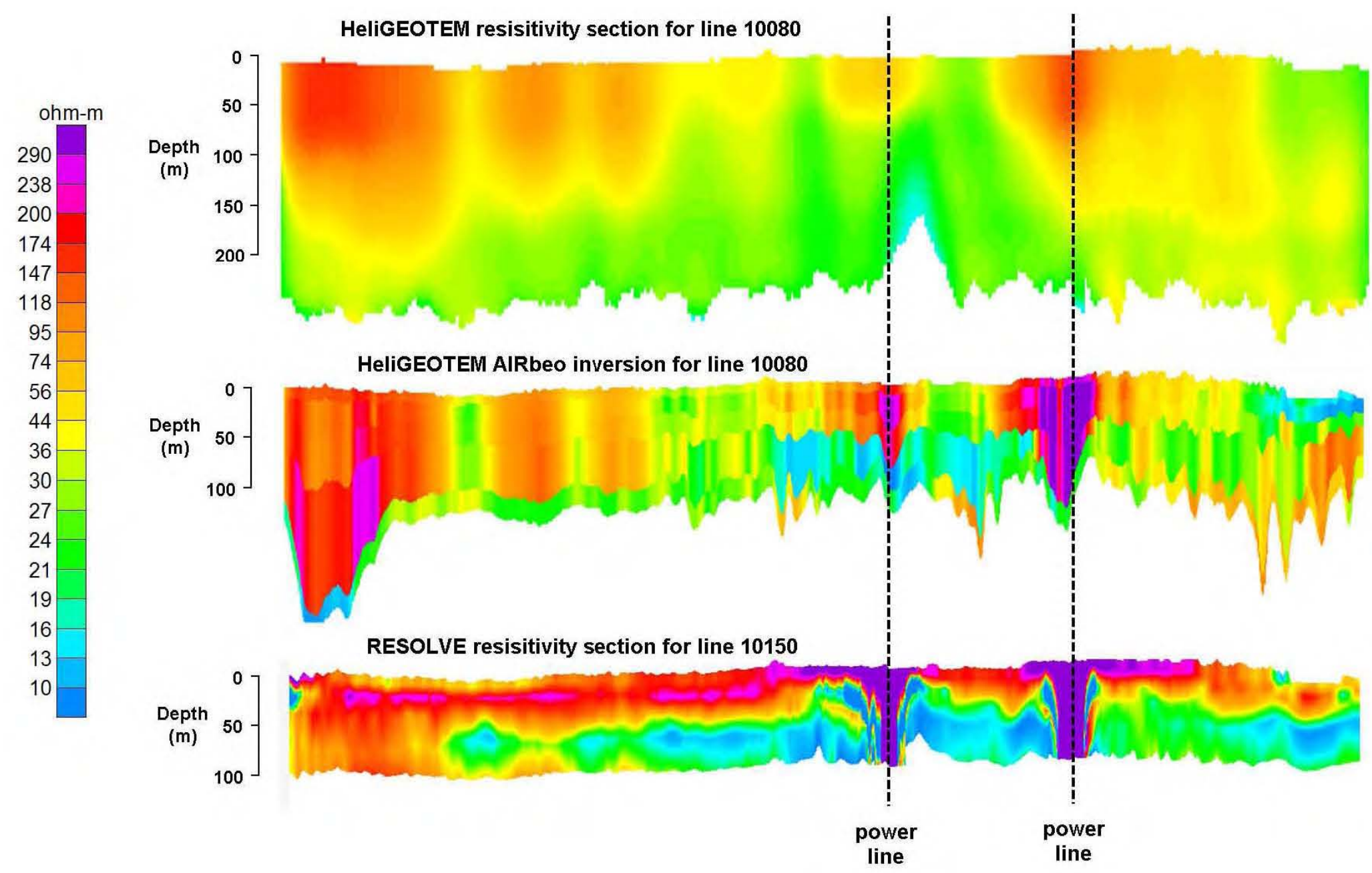

Figure 11: Comparison of the apparent resistivity section and AIRbeo inversion for HeliGEOTEM line 10080 and RESOLVE resistivity section for line 10150 


\section{Well Data and Cross-section Comparison with Survey Data}

An attempt was made to compare the resistivity depth sections from the HeliGEOTEM data with the color geological cross-sections derived from the drill logs. Cross-sections that lie in a north-south orientation coincident with the survey flight lines will yield the best comparison. Unfortunately, only several small sections of a few of the cross-sections are oriented in this manner. Depth sections were cut to provide a close approximation along the cross-sections for comparison. Figure 12 shows the parts of the depth sections that were used to compare with cross-sections E-E', F-F', GG', H-H', I-l', and J-J'. Obviously these comparisons are not perfect, but they do give a good indication of areas where the is a good correlation between the geophysical data and the well data.

The cross-section and depth sections are aligned vertically as closely as possible to allow for a direct comparison between the two. White lines between the color sections indicate where a section grid was cut. It is important to note that grids shown adjacent in these section comparisons may be several lines over on the actual survey block.

The cross-section/depth section comparisons are shown in Figure 12 identifying the resistive features that were interpreted to represent areas of preferential groundwater flow, marked with dashed lines and the letter "A". Also, the approximate locations of power lines are marked with the letter "P", and the approximate location of the interpreted faults are shown as vertical dashed lines. 


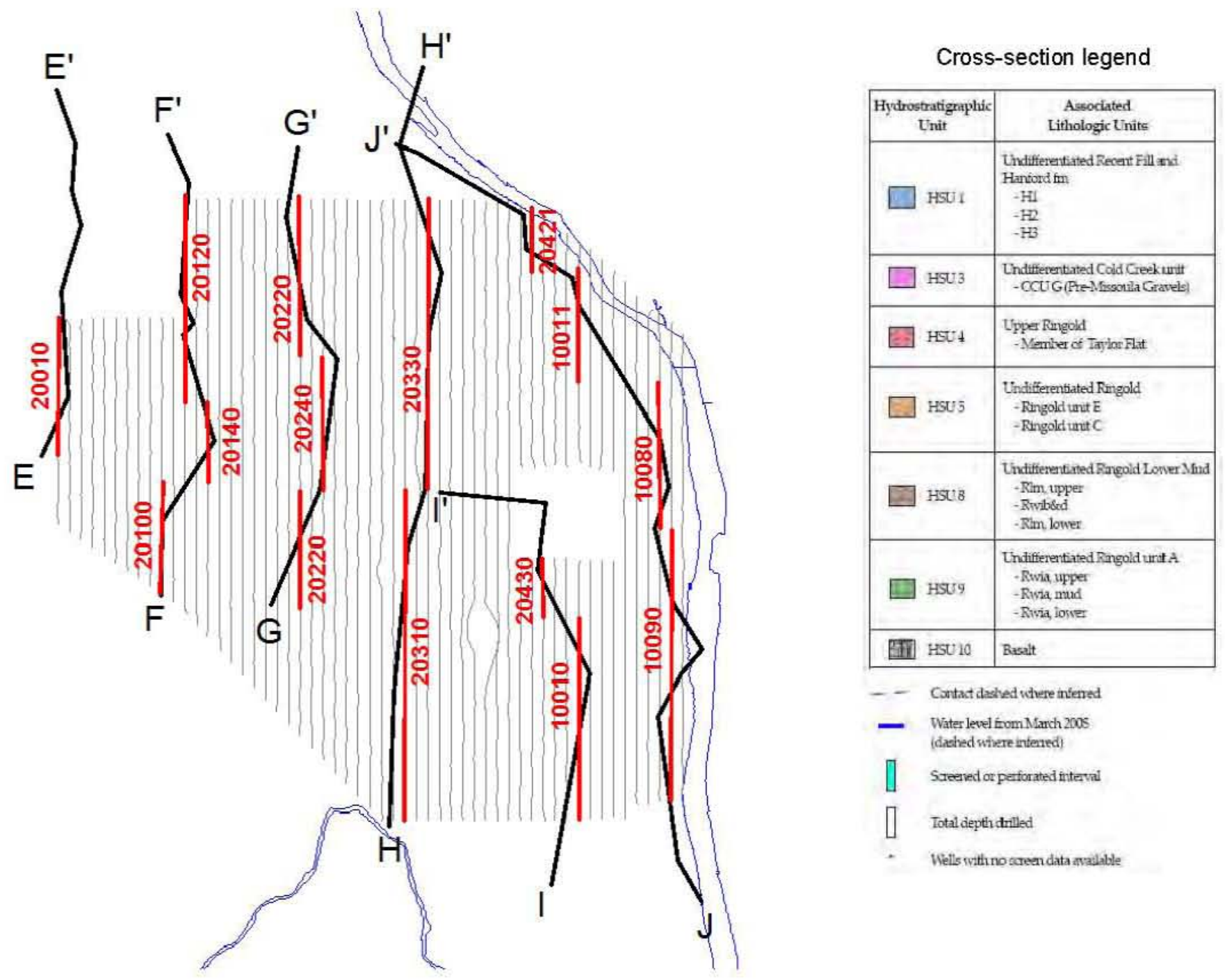

Figure 12: Comparison of cross-sections and the HeliGEOTEM resistivity depth sections as shown in Figure 13 to Figure 18 below. 


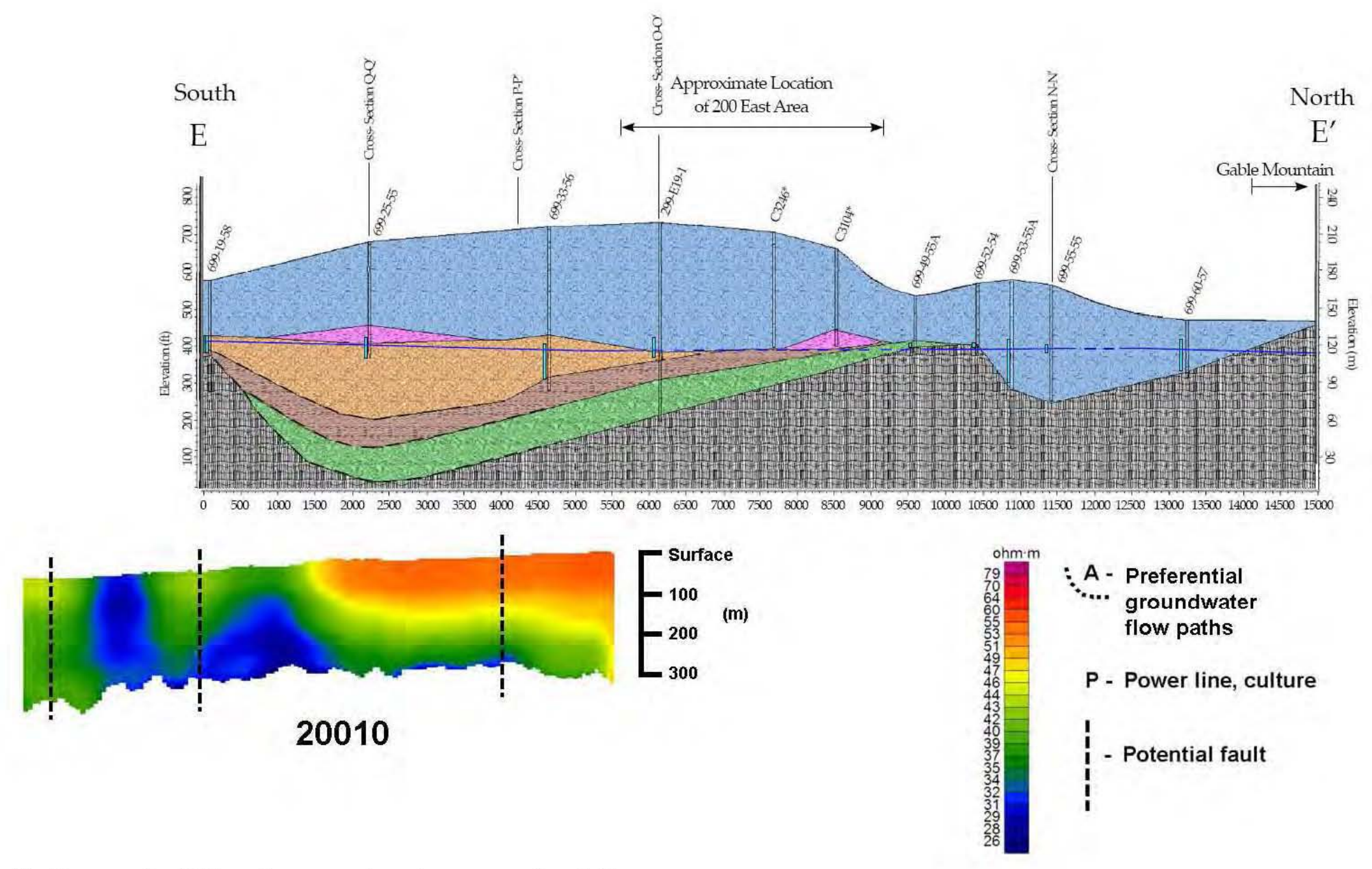

Figure 13: Cross-section/RDI section comparison for cross-section E-E' 


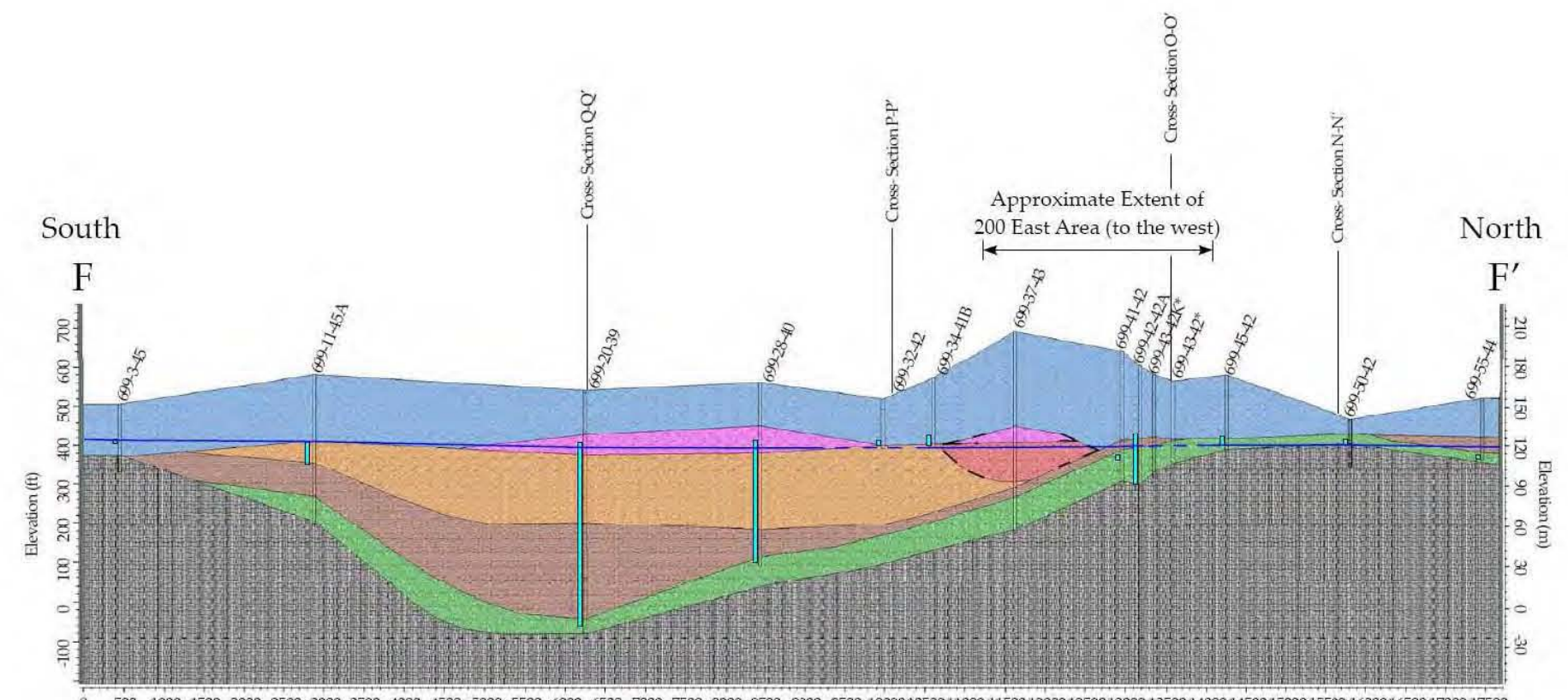

50010001500200025003000350040004500500055006000650070007500800085009000950010000105001100011500120001250013000135001400014500150001550016000165001700017500
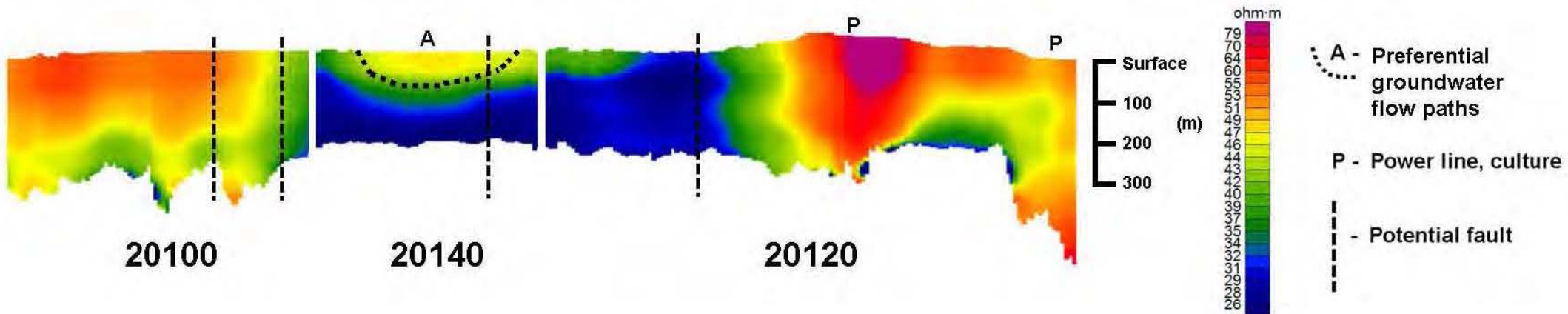

Figure 14: Cross-section/RDI section comparison for cross-section F-F' 


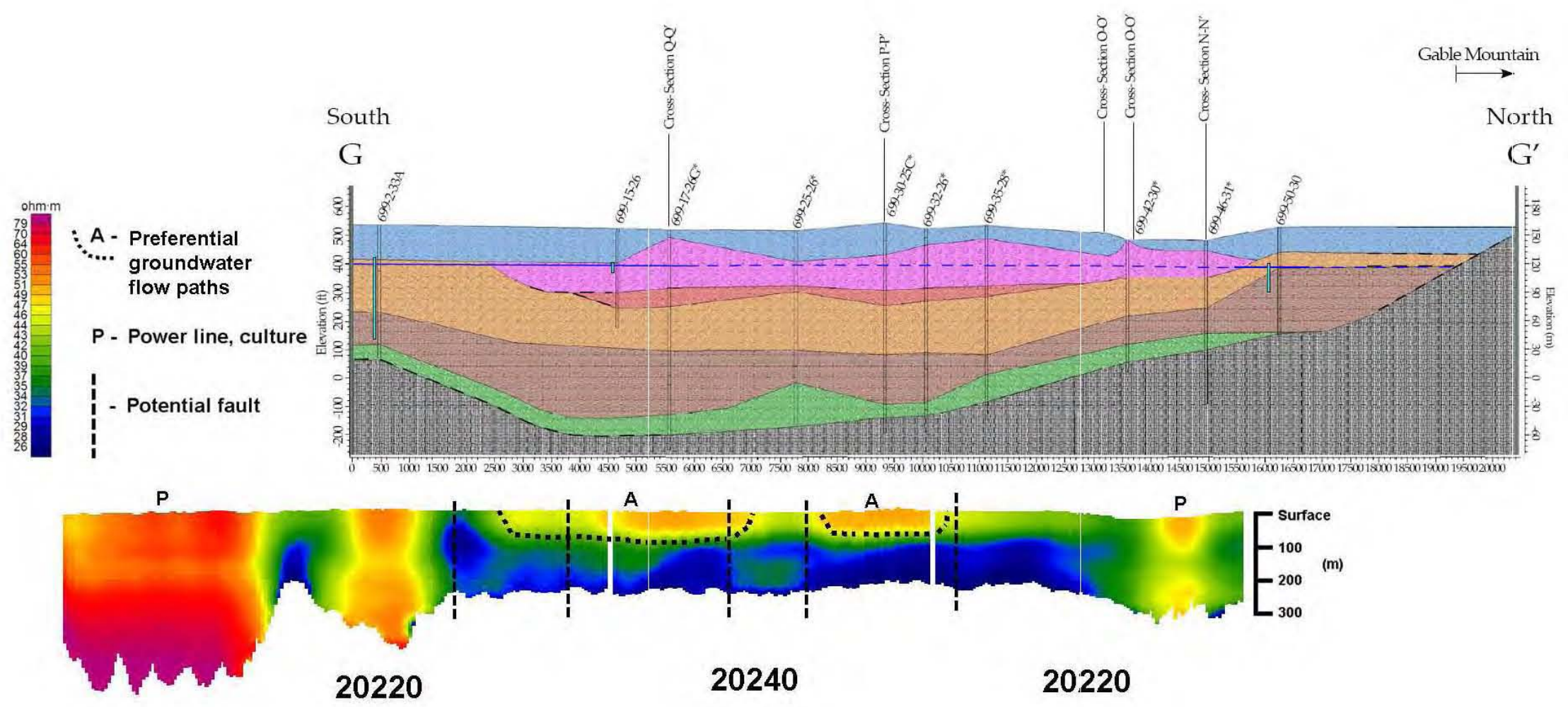

Figure 15: Cross-section/RDI section comparison for cross-section G-G' 


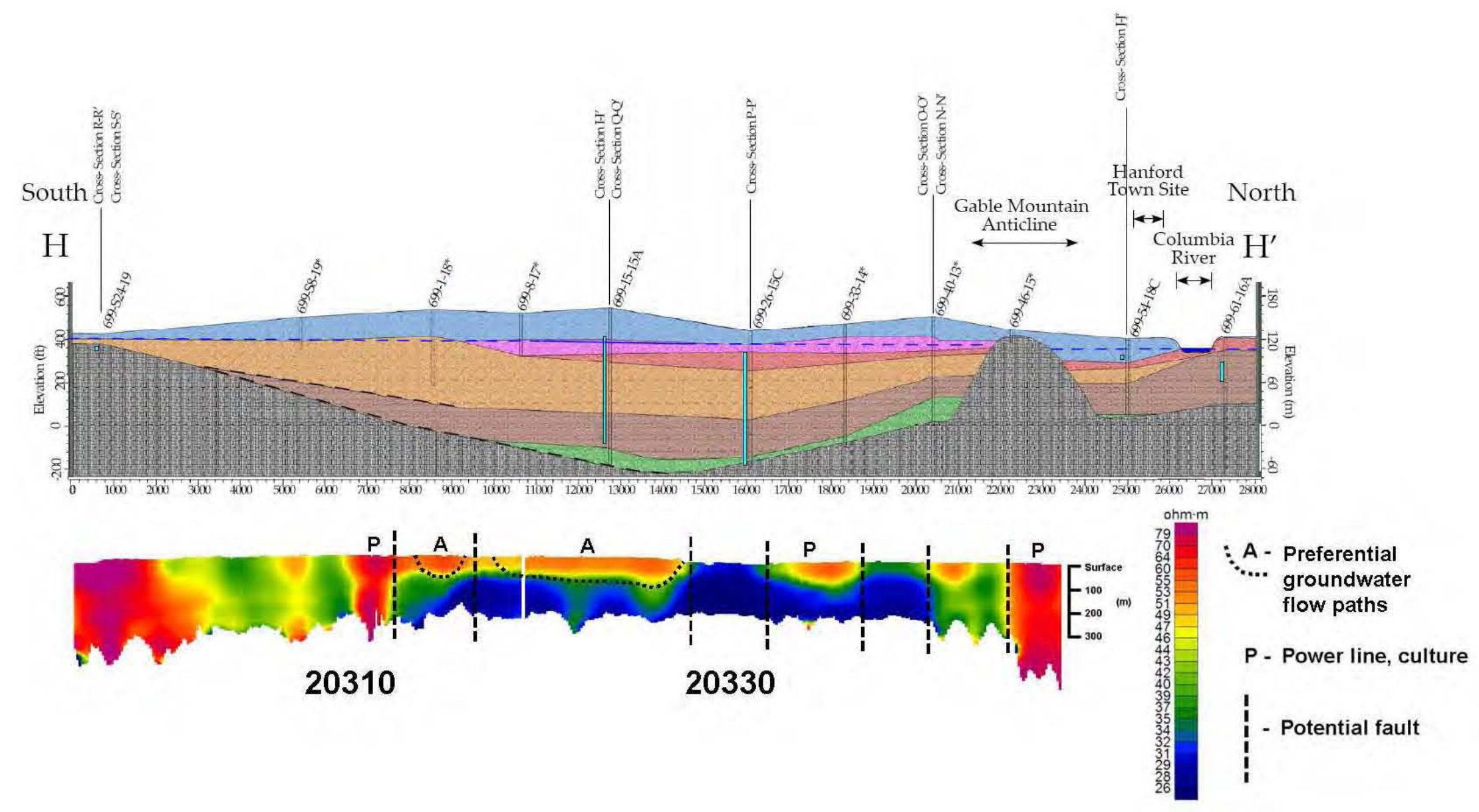

Figure 16: Cross-section/RDI section comparison for cross-section $\mathrm{H}-\mathrm{H}^{\prime}$ 

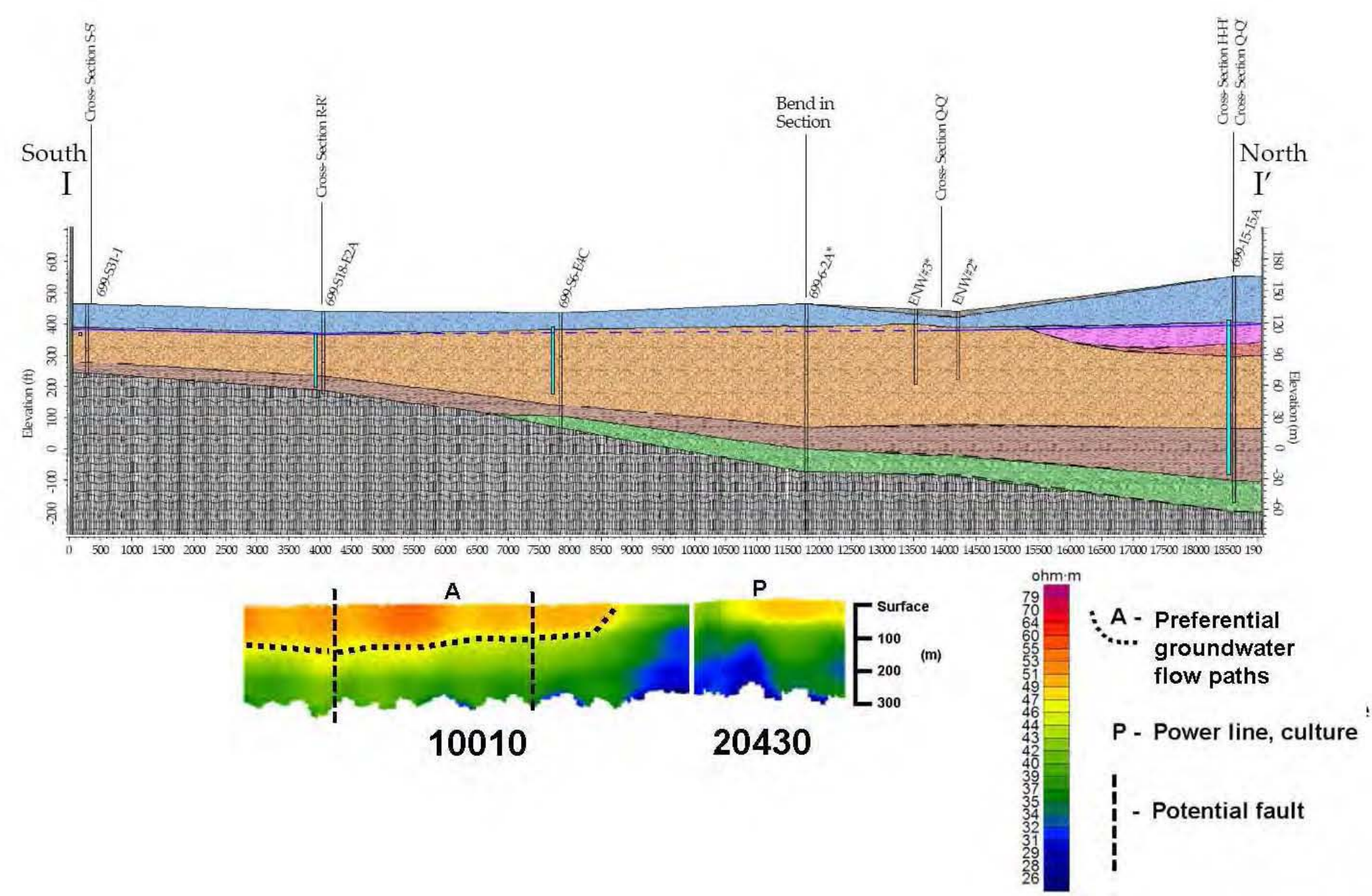

Figure 17: Cross-section/RDI section comparison for cross-section I-I' 

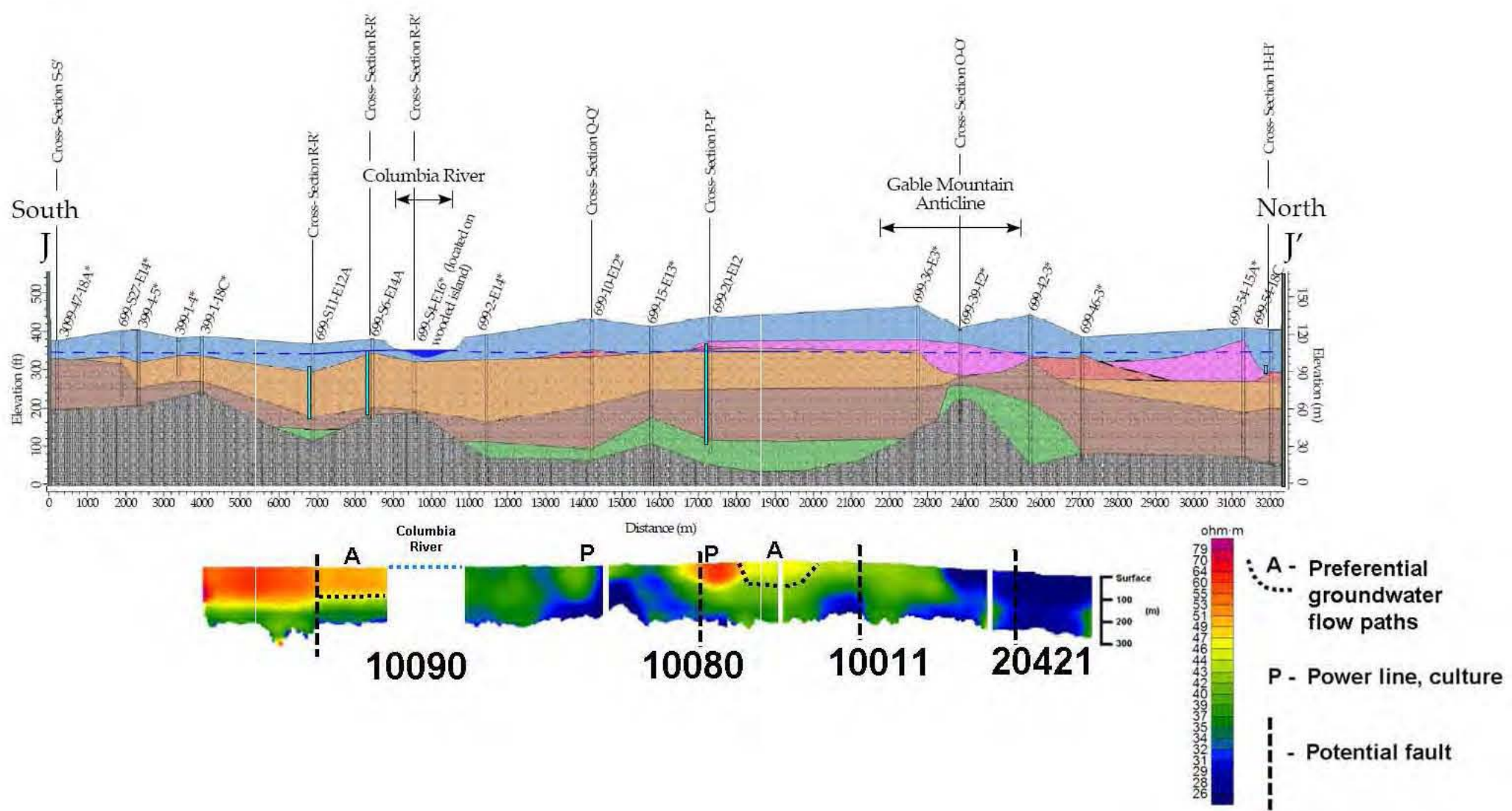

Figure 18: Cross-section/RDI section comparison for cross-section J-J' 


\section{V \\ Discussion}

\section{Resistive Near-surface Basalt}

Several resistive features are outlined on the interpretation map which appear to be a response from basalt sub-cropping close to surface. In most cases the cross-sections and drill information confirms that the basalt lies near surface, however this interpretation is also supported by the EM and magnetic response. Figure 19 shows the interpreted zones of near surface basalt over the residual magnetic intensity, first vertical derivative and the "deep" resistivity depth slice. The zoned areas display a good correlation between strong resistive features that are fairly consistent with depth and some of the stronger, shorter wavelength magnetic responses which are consistent with near surface bedrock formations. Areas interpreted as preferential groundwater flow paths generally show a thinner resistive layer with more conductive material beneath, likely a response to more conductive sediments at depth.

Cross-section $\mathrm{H}-\mathrm{H}^{\prime}$ is a good example of this, where the southern end of the section shows basalt at about 12 meters depth (hole 699-S24-19), and the Gable Mountain Anticline is shown to be at about 9 meters depth (hole 699-46-15). Each of these locations show a significant resistive area on the depth sections.

F-F' Cross-section shows basalt approaching surface at both the north and south ends, corresponding with a resistive feature in both cases.

This information may help fill in some of the inferred areas on the cross-sections where the depth to basalt is not well mapped. 

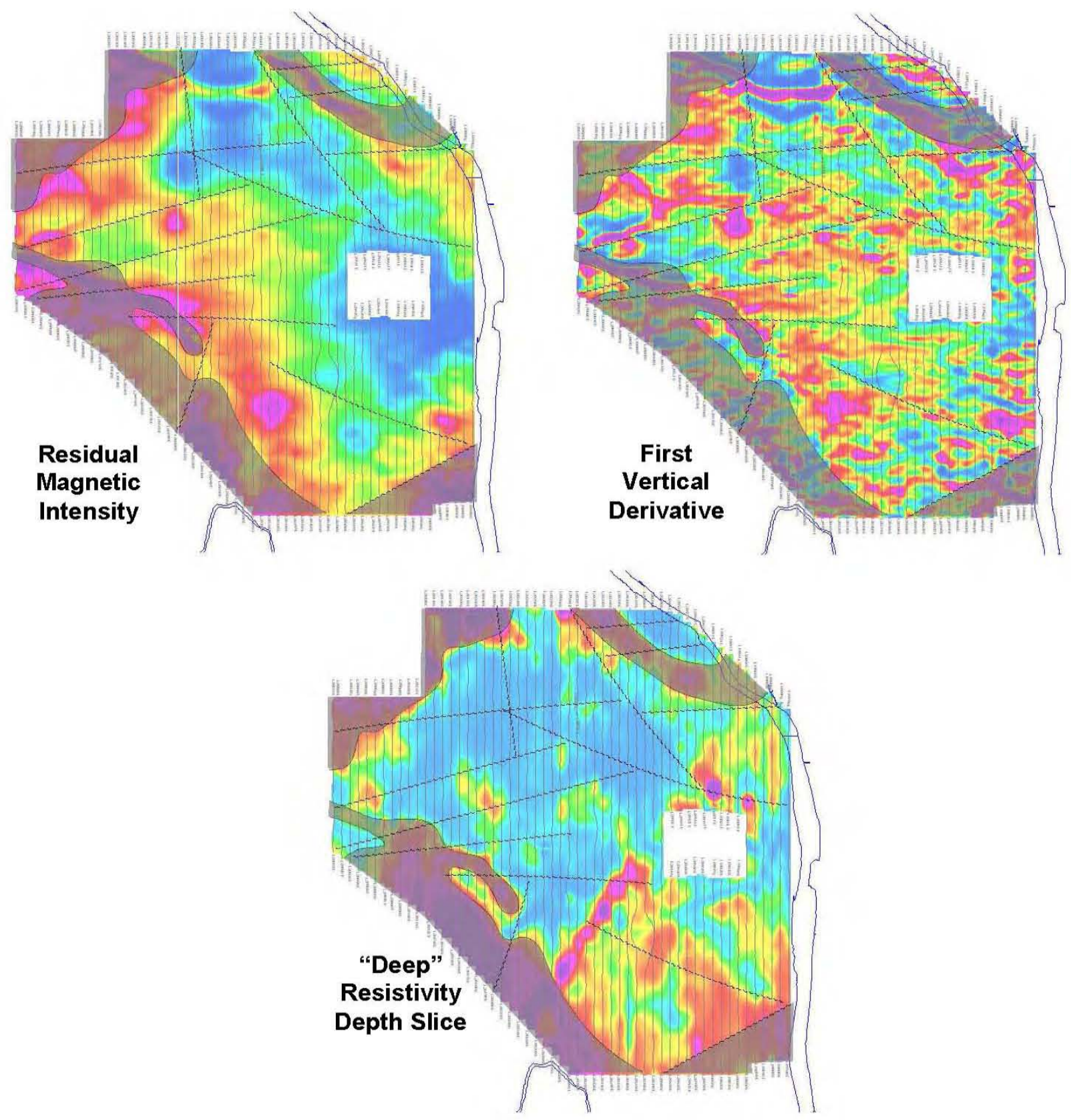

Figure 19: Zones interpreted as resistive basalt formations lying near-surface. 

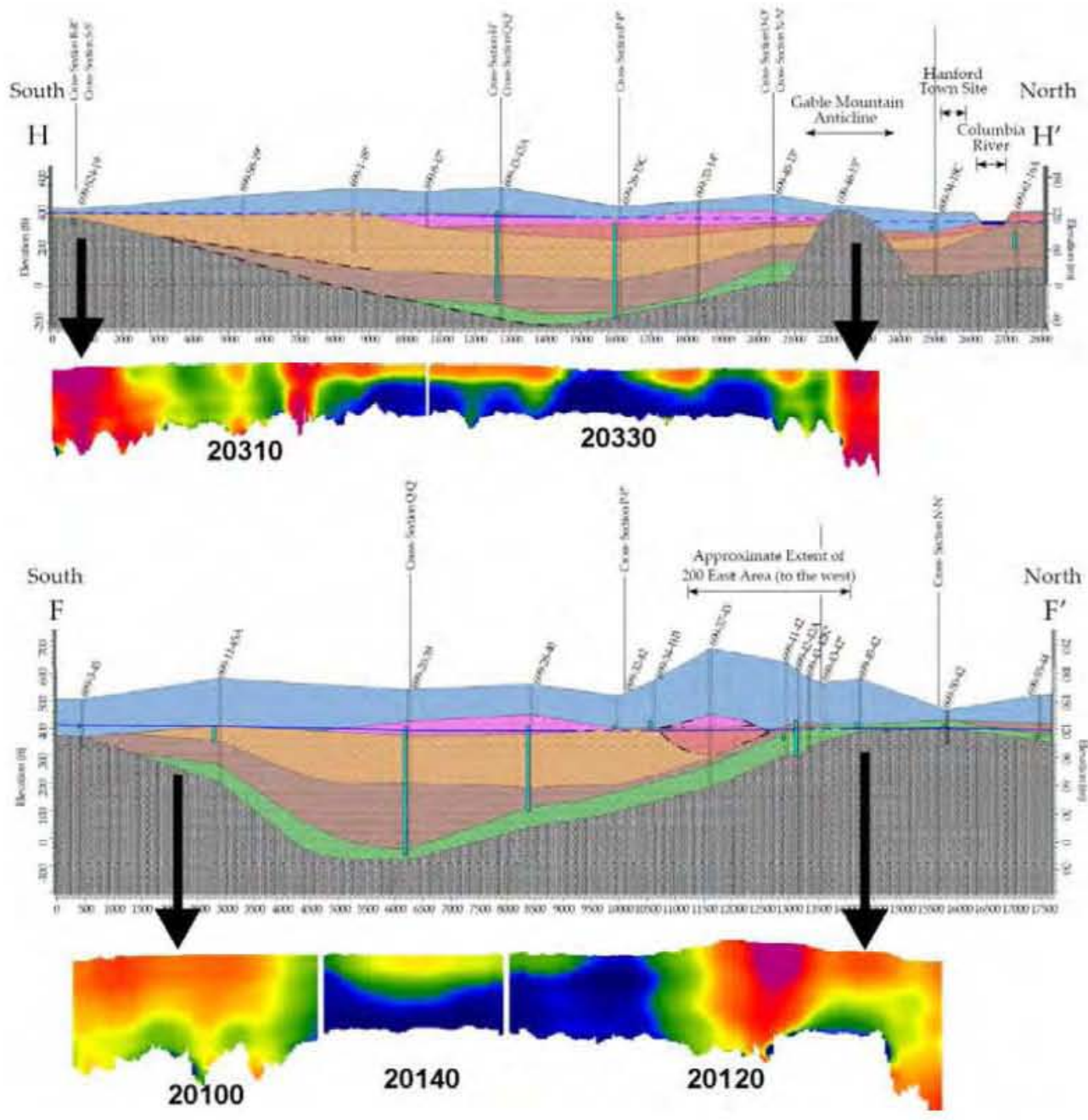

Figure 20: EM response to shallow basalt along cross-section $\mathrm{H}^{-\mathrm{H}^{\prime}}$ and $\mathrm{F}-\mathrm{F}$ ' 


\section{Interpreted Preferential Groundwater Flow Paths}

The interpretation map shows likely preferential groundwater flow paths interpreted from the airborne EM data. These are shown as shallow, mid depth, or deep based on where the strongest apparent resistivities are measured on the depth slices. A shallow response is likely from the near surface down to about 60 meters, a mid-depth response would likely be from about 80 to 120 meters and a deep response would be from greater than 120 meters depth. As previously discussed, the HeliGEOTEM system measures a response from a broad footprint and will not necessarily delineate a thin layer with weakly contrasting resistive properties. Therefore the preferential groundwater flow paths interpreted in this report represent areas within the sediments in the order of 10 s of meters thick which could represent a resistive unit of unconsolidated material such as coarse sediments or gravel, or a paleochannel.

The interpretation identifies essentially one major northwest-southeast trending preferential flowpath with several minor units running along a similar trend. Figure 21 shows the preferential groundwater flow paths with the basalt elevation contours. A good correlation is noted with the northwest-southeast trend of the "basin" of the basalt. Figure 22 shows the preferential groundwater flow paths with the Tritium contours. 


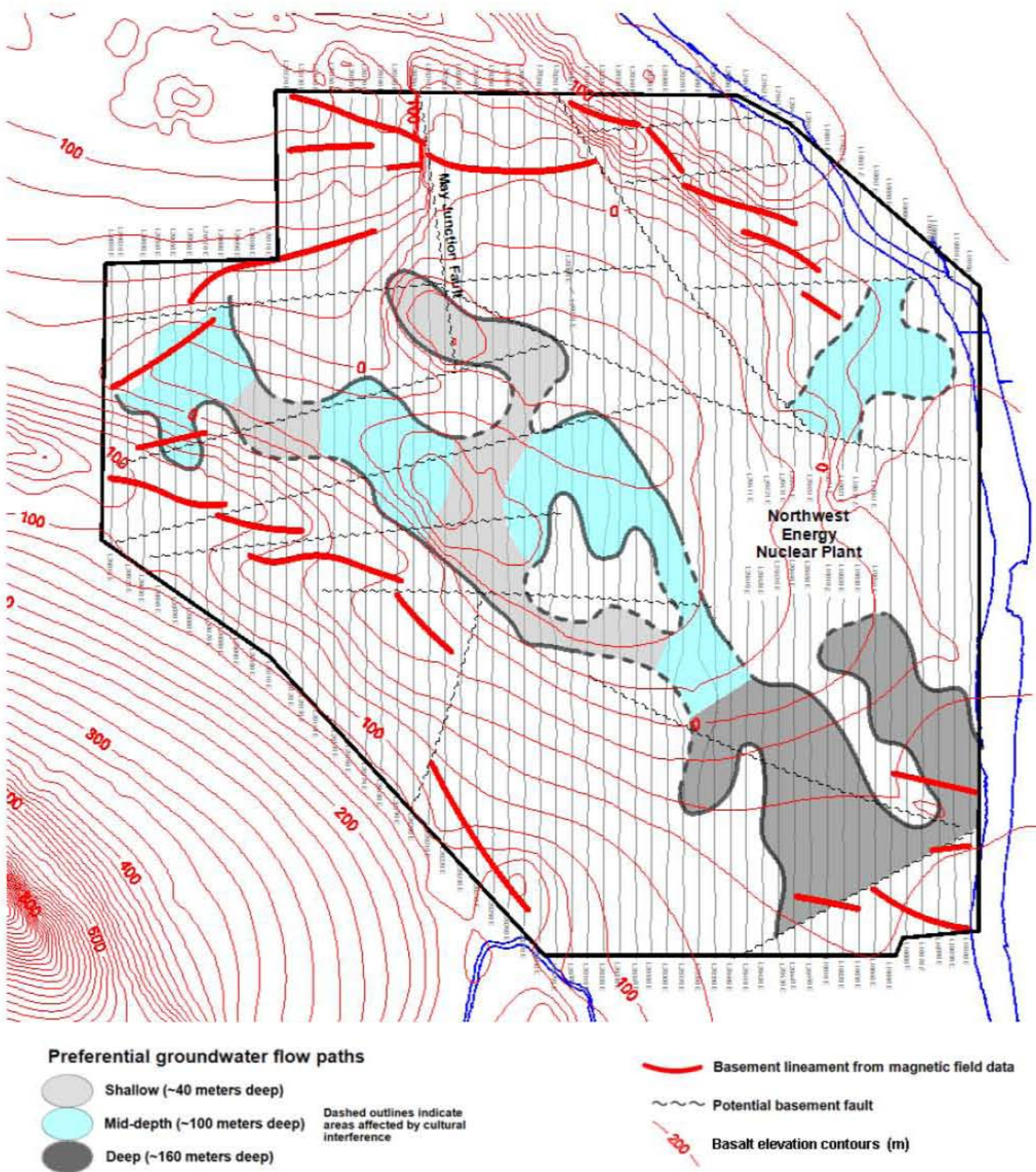

Figure 21: Interpreted preferential groundwater flow paths displayed over the basalt elevation contours shown in red. Basement lineaments shown in thicker red. Preferential groundwater flow paths and basement lineaments show good correlation with basalt elevations. 


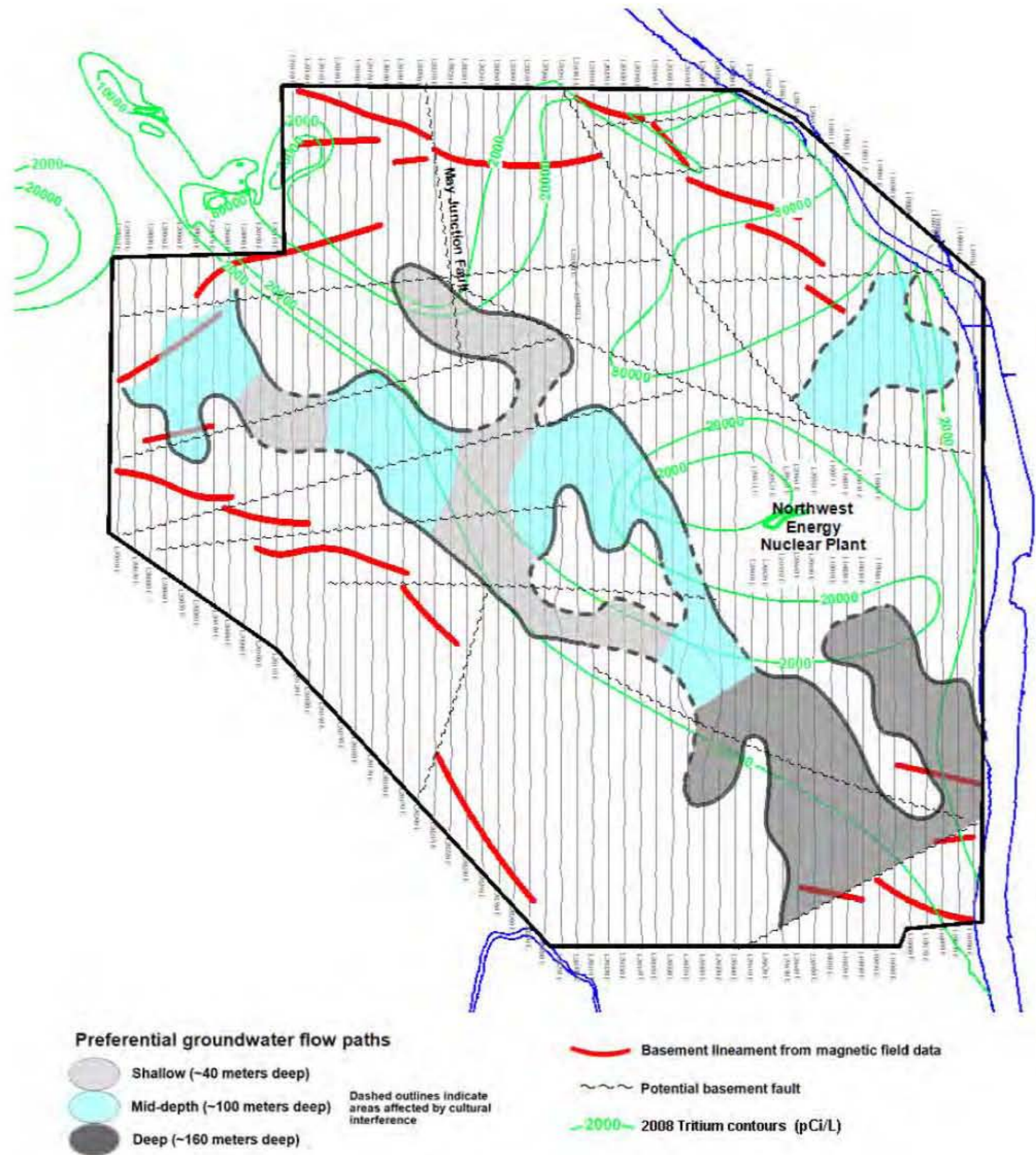

Figure 22: Interpreted preferential groundwater flow paths displayed over the tritium plume contours shown in green. Basement lineaments shown in thick red. 


\section{VI}

\section{Conclusions}

The interpretation of the HeliGEOTEM and RESOLVE apparent resistivity data has outlined several zones of relatively higher resistivity which are presumed to represent potential preferential groundwater flow zones within the supra-basalt sediment column at the Hanford site. These selections are based on the data provided by these survey systems, which of course is not an exact measurement of the ground. The results are an interpretation of the data to fit the target model.

Analysis of the magnetic field data shows the location of potential bedrock faults and lineaments which may influence the horizontal and vertical flow of water. Faults lying within, or in the vicinity of preferential groundwater flow paths may allow flow into or out of the otherwise confined basalt layers.

The combined response from the EM and magnetic field datasets has also delineated areas where the basalt layer appears to approach the surface which may limit the horizontal flow of water though aquifers in the area. These geophysical systems are not effective in mapping the depth of the basalt throughout the dataset as drill results suggest that the basalt lies beyond the depth of penetration of the instruments over much of the area.

Due to the abundant sources of cultural noise, the confidence in the extent and continuity of some of the resistive features is limited. 